THE CAREERS OF MODERN ARTISTS:

EVIDENCE FROM AUCTIONS OF

CONTEMPORARY PAINTINGS

David W. Galenson

Working Paper 6331 
NBER WORKING PAPER SERIES

\section{THE CAREERS OF MODERN ARTISTS: \\ EVIDENCE FROM AUCTIONS OF CONTEMPORARY PAINTINGS}

David W. Galenson

Working Paper 6331

http://www.nber.org/papers/w6331

\section{NATIONAL BUREAU OF ECONOMIC RESEARCH 1050 Massachusetts Avenue \\ Cambridge, MA 02138 \\ December 1997}

Discussions with Gary Becker, Tim Conley, Allison Gamble, Julie Garfield, Randy Kroszner, Gracie Mansion, Nancy Mozur, Alison Pearlman, Carolyn Sargent, Tom Sargent, Susanna Singer, and Lester Telser helped me identify issues and sources, and I thank them for their advice and encouragement. Sean Buckley provided excellent research assistance. Any opinions expressed are those of the author and not those of the National Bureau of Economic Research.

(C) 1997 by David W. Galenson. All rights reserved. Short sections of text, not to exceed two paragraphs, may be quoted without explicit permission provided that full credit, including $(\mathcal{O}$ notice, is given to the source. 
The Careers of Modern Artists: Evidence from

Auctions of Contemporary Paintings

David W. Galenson

NBER Working Paper No. 6331

December 1997

JEL No. J24

\begin{abstract}
Using transactions from fine art auctions for 42 leading American contemporary artists I estimate the relationship between the value of a painting and the artist's age at the date of its execution. The econometric estimates show that artists born before 1920 were likely to have done their most valuable work late in their careers, while in contrast artists born in the 1920 s and 30s were more likely to have done their most valuable work at an early age. Comparison of these results to evidence drawn from art history textbooks and museum exhibitions furthermore indicates that these artists' most valuable work has also been that most highly regarded by scholars. I argue that the shift across generations in the shape of these artists' age-price profiles was a result of both the evolution of modern painting and a growth in the demand for contemporary American art during the 1950s and $60 s$.
\end{abstract}

David W. Galenson

Department of Economics

University of Chicago

1126 East 59th Street

Chicago, IL 60637

and NBER

shirl@cicero.spc.uchicago.edu 
The Careers of Modern Artists: Evidence from Auctions of Contemporary

\section{Paintings}

David W. Galenson ${ }^{1}$

University of Chicago

National Bureau of Economic Research

November 6, 1997

\section{Introduction}

Economists have long been interested in how workers' productivity varies with age, and have devoted considerable effort to measuring this relationship in a variety of settings. Yet few markets generate evidence that allows economists to observe this relationship throughout the careers of specific individuals. One that does produce evidence relevant to this is the market for fine art. This paper will use records of paintings sold at auctions since 1980 to estimate the relationship between artists' ages and the value of their work for a group of successful twentieth-century artists. Although this does not fully capture these artists' productivity, because it does not take into account the volume of their work, the value of an artist's work over his career is nonetheless of interest for its

\footnotetext{
${ }^{1}$ Discussions with Gary Becker, Tim Conley, Allison Gamble, Julie Garfield, Randy Kroszner, Gracie Mansion, Nancy Mozur, Alison Pearlman, Carolyn Sargent, Tom Sargent, Susanna Singer, and Lester Telser helped me identify issues and sources, and I thank them for their advice and encouragement. Sean Buckley provided excellent research assistance.
} 
indication of how the quality of the artist's work varies with age.

The painters studied in this paper are among the most prominent artists whose work is sold in auctions of Contemporary Art. This is a category introduced in the auction market by Sotheby's, and broadly includes artists who have become known since World War II. ${ }^{2}$ The 42 artists considered in this study are listed in Table 1. All are important contemporary artists. They are not intended to include all important contemporary artists, or all the members of any particular school of art, but they do share some broad common characteristics. ${ }^{3}$ Most were born after 1900, and all were born before 1940. Most were born in the United States, and all spent much, if not most, of their careers in the US. And all are sufficiently successful that auctions held in recent years have included enough of their work to allow the statistical analysis reported below.

There are a number of periods that could be considered by a study of this

\footnotetext{
${ }^{2}$ Peter Watson, From Manet to Manhattan: The Rise of the Modern Art Market (New York: Random House, 1992); pp. 416-18; Anthony Haden - Guest, True Colors: The Real Life of the Art World (New York: Atlantic Monthly Press, 1996), p. 1-17. Sotheby's first established a separate Contemporary Art department in 1970. Its first major event was the sale of Robert Scull's collection in 1973. This was the first contemporary sale devoted to a single collection, and resulted in record total receipts for the category, as well as record prices for the work of 10 individual artists. The auction was intentionally planned, in Scull's words, to "prove to the world that American art has found its place in history ... with buyers, with people who believe in it;" quoted in John Tancock, "The Robert C. Scull Auction," Art at Auction: The Year at Sotheby Parke Bernet, 1973-74 (New York: Viking Press, 1974), p. 138. The success of the Scull sale convinced the major auction houses to schedule contemporary sales regularly.

${ }^{3}$ For detailed biographical information and references for many of these painters, see e.g. Irving Sandler, The Triumph of American Painting: A History of Abstract Expressionism (New York: Praeger, 1970), and Sandler, The New York School: The Painters and Sculptors of the Fifties (New York: Harper and Row, 1978), pp. 321-25.
} 


\begin{tabular}{|c|c|c|c|c|c|c|c|c|c|c|c|c|c|c|c|c|c|c|c|}
\hline 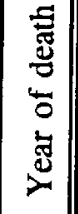 & ప̃ & $\overline{\mathrm{a}}$ & ఏำ & & & $\stackrel{\circ}{\circ}$ & & $\begin{array}{c}n \\
\vdots \\
\vdots\end{array}$ & & $\stackrel{\S}{\circ}$ & & & 号 & & $\begin{array}{l}\stackrel{\circ}{\circ} \\
\stackrel{2}{*}\end{array}$ & & $\begin{array}{l}0 \\
0 \\
0\end{array}$ & & వ) \\
\hline 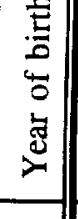 & $\stackrel{\square}{\Xi}$ & $\stackrel{n}{a}$ & $\stackrel{\varrho}{\varrho}$ & $\Xi$ & $\tilde{\Xi}$ & $\frac{\pi}{\square}$ & $\stackrel{0}{=}$ & 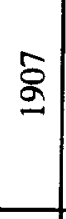 & ఏ & $\stackrel{m}{2}$ & $\stackrel{2}{2}$ & 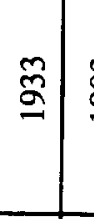 & 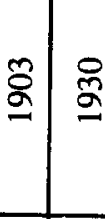 & $\stackrel{0}{0}$ & $\mid \begin{array}{l}\vdots \\
\vdots \\
\sigma\end{array}$ & 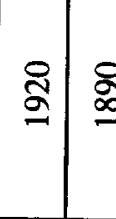 & 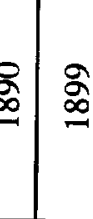 & $\stackrel{\infty}{\sigma}$ & $\stackrel{\text { I }}{\Xi}$ \\
\hline 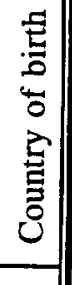 & 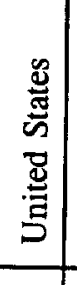 & 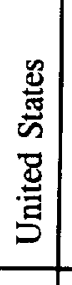 & 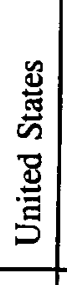 & 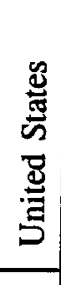 & 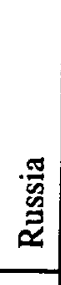 & 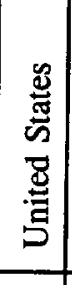 & 急 & 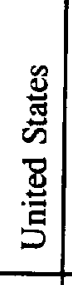 & 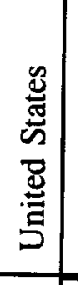 & 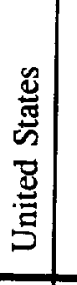 & 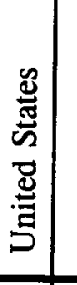 & 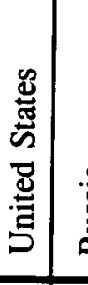 & 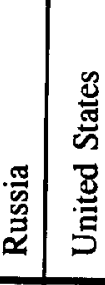 & 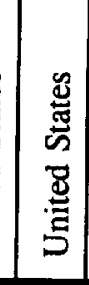 & 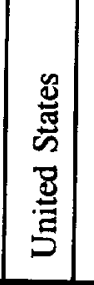 & 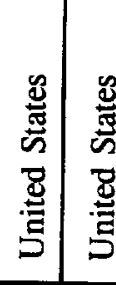 & 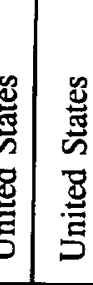 & 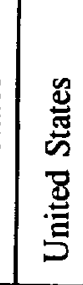 & 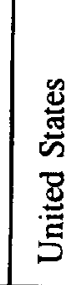 \\
\hline$\frac{\vec{m}}{\underline{\underline{\varepsilon}}} \|$ & 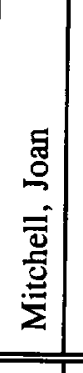 & 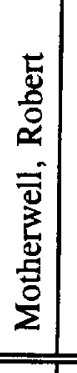 & 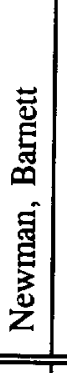 & 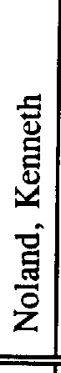 & 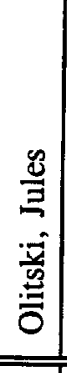 & 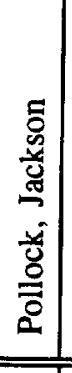 & $\begin{array}{r}1 \\
0 \\
0 \\
0 \\
0 \\
0 \\
\end{array}$ & 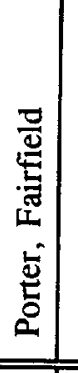 & 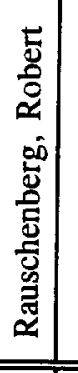 & 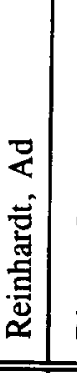 & 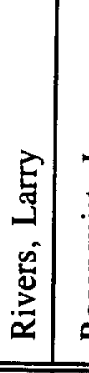 & & 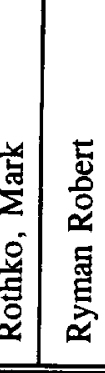 & 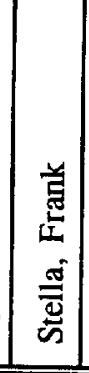 & 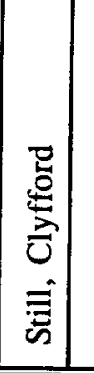 & 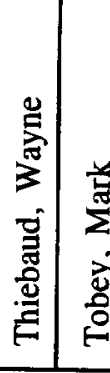 & 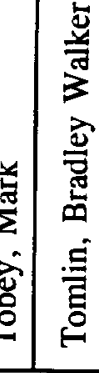 & 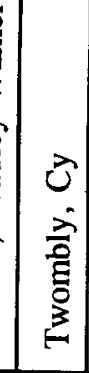 & 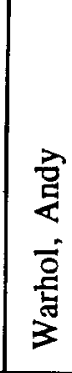 \\
\hline 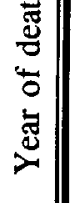 & 品 & 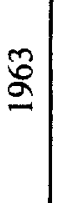 & & & 㟢 & & 足 & 売 & $\stackrel{\circ}{\stackrel{\Xi}{2}}$ & & 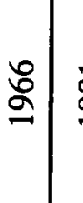 & $\overrightarrow{\mathrm{g}}$ & & ڤ్ర & a & ఏ & $\underset{\sigma}{\sigma}$ & & \\
\hline 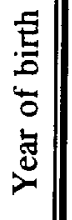 & $\stackrel{\substack{\infty \\
\stackrel{\infty}{\rightarrow}}}{=}$ & $\Xi$ & $\Xi$ & $\stackrel{m}{2}$ & $\stackrel{\tilde{\Xi}}{\varrho}$ & $\stackrel{2}{\Xi}$ & 壳 & 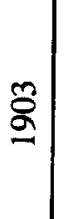 & $\frac{m}{2}$ & $\tilde{\hat{n}}$ & 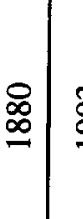 & 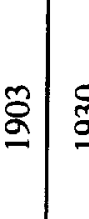 & 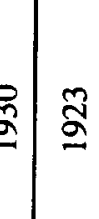 & $\stackrel{\circ}{\circ}$ & 苛 & 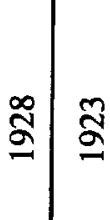 & $\frac{\pi}{\varrho}$ & $\tilde{\tilde{g}}$ & $\stackrel{\infty}{\varrho}$ \\
\hline | & 帘 & | & | & 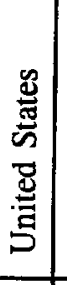 & 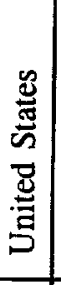 & 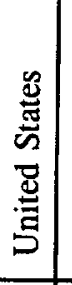 & & | & 恕 & 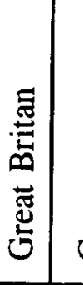 & & 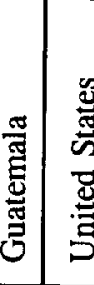 & 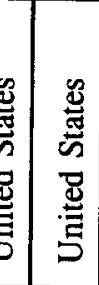 & 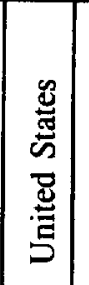 & 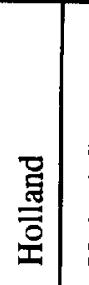 & 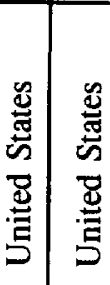 & 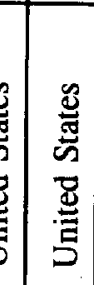 & 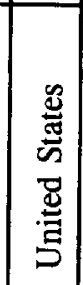 & 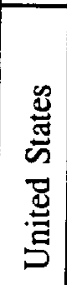 \\
\hline 妾 & 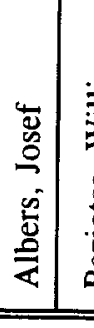 & 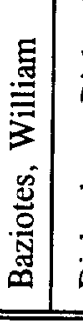 & 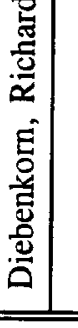 & 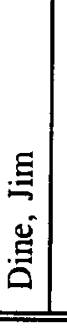 & & 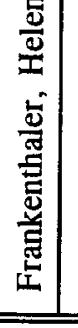 & 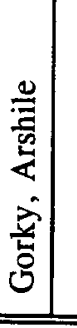 & 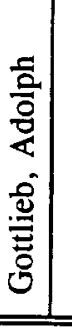 & & & 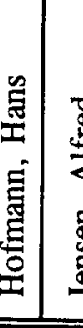 & 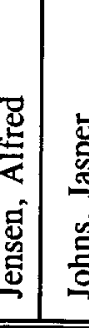 & 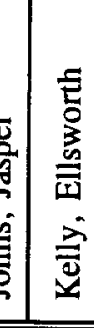 & 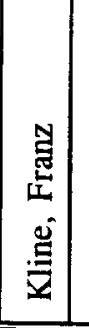 & 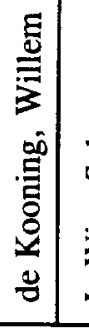 & 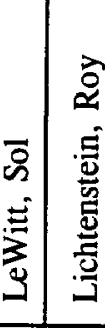 & 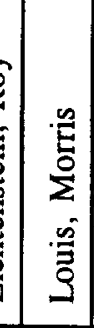 & 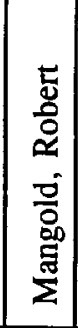 & 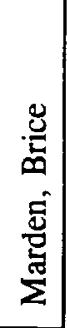 \\
\hline
\end{tabular}


kind, and the same is true of the particular artists chosen for the analysis. Yet there are advantages to the choices made here. Documentation is very good for recent art: not only are questions concerning authenticity rare, but dating of work is usually precise. Considering a sizeable group of artists who worked in the same country during a relatively short period offers the possibility of identifying common patterns in the careers of artists from a particular era, in a similar social and economic setting. The artists considered here form a particularly interesting group, for they include the painters who dominated modern art for two generations after World War II, and who for the first time established the United States as the source of the major developments in western art. ${ }^{4}$

The results of this study are intriguing. Many occupations that involve extensive training and complex technical abilities produce rising skill levels of practitioners, and rising quality of work, over an extended period. The evidence analyzed here suggests that this was generally true for the generation of American artists born in the first two decades of this century, but that it ceased to be true for the following generation, those born in the 1920s and '30s. This shift appears to have important implications for our understanding of the careers of contemporary artists: why were major American artists born before 1920 likely

\footnotetext{
${ }^{4}$ Many art historians have written on this theme. The earliest extended statement of it may have been in a 1955 essay by the critic Clement Greenberg; see Greenberg, Affirmations and Refusals, 1950-1956 (Chicago: University of Chicago Press, 1993), pp. 217-35.
} 
to have done their most valuable work late in their careers, while their successors born after 1920 are more likely to have done their most valuable work early in their careers? The answer appears to highlight a dramatic change in the economic incentives for artists that occurred during the 1950s, as a result of an interaction of the evolution of modern painting with an increase in the demand for American art.

\section{Data and Econometric Analysis}

The data analyzed in this paper are drawn from auctions held during 198096. The source of these data is the annual editions of Le Guide Mayer, which compiles the results of fine art auctions held all over the world. ${ }^{5}$ Mayer classifies the works sold into five groups: prints; drawings; watercolors; paintings; and sculptures. This study collected the records of all sales for the 42 artists listed in Table 1 from the 17 annual editions of Mayer for auctions held during 1980-96 in the two categories of watercolors and paintings. ${ }^{6}$ This yielded a total of 4,532 sales of individual works. Most of these sales occurred in the United States, and nearly $90 \%$ were sold by the two leading auction houses, Sotheby's and Christie's.

\footnotetext{
${ }^{5}$ Le Guide Mayer (Lausanne: Sylvio Acatos, annual).

${ }^{6}$ For Sol LeWitt, all works listed as drawings were also collected. Choosing a starting date for data collection involved consideration of a tradeoff: lengthening the period increases the number of transactions, but also increases the probability of changes in the relative demand for an artist's work at different ages, which poses problems for econometric analysis of the age-price relationship. The choice of 1980 as the starting date for this study was made because the volume of auction transactions in contemporary art increased considerably after the 1970s.
} 
For each painting in the data set, the coding for this study recorded the support (paper or canvas), size, date of execution, date sold, and sale price. ${ }^{7}$

For the econometric analysis, each painting sold constituted a single observation. Separate regression equations were specified for each artist. The dependent variable was the natural logarithm of the sale price in dollars. ${ }^{8}$ The principal interest of this study was in the impact on a painting's auction price of the artist's age at the time of its execution. To test for the best form for this relationship, three regressions were estimated for each artist, the first with the artist's age as an independent variable, the second with age and its square, and the third with age, its square, and its cube. A binary independent variable was included to indicate whether the work was done on paper or canvas. The size of the work was controlled, using the natural logarithm of the surface area. Substantial fluctuations occurred in the art market during the 1980s and early '90s, so independent variables were included to allow for the effect of the date at which the work was auctioned.

$\underline{\text { Regression Estimates of Age - Price Profiles }}$

The estimated regressions for the 42 artists considered in the study are pre-

\footnotetext{
${ }^{7}$ The sale price given by Mayer is the hammer price, i.e. it includes the commission charged by the auction house to the seller, but not the premium charged to the buyer. The standard rate for the latter is $10 \%$ of the hammer price. On the origin of the buyer's premium, see Watson, From Manet to Manhattan, pp. 353-54. Mayer does not report prices for works that were bought in, i.e. that failed to reach their reserve prices.

${ }^{8}$ The prices were converted to constant 1983 dollars using the CPI.
} 
sented in the appendix. Of the three specifications estimated for each artist, the one reported is that which produced the best fit, as measured by the adjusted $R^{2}$. For each case in which the second or third variant is reported, the table also shows the results of an $F$ test for the joint statistical significance of the age variables. Overall, age had a statistically significant effect on the value of an artist's work for 31 of the 42 artists considered..$^{9}$ For these 31 , Table 2 shows the age at which the value of the artist's work peaked, as calculated from the estimated age coefficients shown in the appendix.

With the artists listed in order of their birthdates, Table 2 shows a striking change over time. Fourteen of the artists included in the table were born from 1880 through 1920 . For 13 of these 14, the value of their work peaked above the age of 40 ; for 8 , the value peaked at 50 or above. In contrast, for the 17 artists born after 1920, the value of the work of 13 peaked below the age of 40 ; for 7 , their most valuable work was done during their 20 s. The median age at which the peak value of their work occurred was 52 for the 14 artists born through 1920 , while the median age for the 17 born after 1920 was 32 . Thus considering those artists for whom age significantly affected the value of their work, more than $90 \%$ of those born through 1920 did their most valuable work after the age of 40 , while more than three-quarters of those born after 1920 did their most valuable work

\footnotetext{
${ }^{9}$ The .10 level is used as the criterion for statistical significance.
} 
Table 2: Estimated Peaks of Age-Price Profiles, by Artist

\begin{tabular}{||l|c|c||l|c|c||}
\hline Artist & Year of birth & Peak Age & Artist & Year of birth & Peak Age \\
\hline \hline Hofmann & 1880 & 84 & Kelly & 1923 & 42 \\
\hline Tomlin & 1899 & 54 & Lichtenstein & 1923 & 41 \\
\hline Rothko & 1903 & 57 & Rivers & 1923 & 40 \\
\hline Gorky & 1904 & 43 & Noland & 1924 & 33 \\
\hline De Kooning & 1904 & 44 & Rauschenberg & 1925 & 30 \\
\hline Porter & 1907 & 68 & Frankenthaler & 1928 & 27 \\
\hline Kline & 1910 & 48 & LeWitt & 1928 & 32 \\
\hline Baziotes & 1912 & 44 & Twombly & 1928 & 24 \\
\hline Louis & 1912 & 50 & Warhol & 1928 & 33 \\
\hline Pollock & 1912 & 37 & Johns & 1930 & 25 \\
\hline Guston & 1913 & 66 & Rosenquist & 1933 & 28 \\
\hline Reinhardt & 1913 & 45 & Stella & 1936 & 21 \\
\hline Motherwell & 1915 & 72 & Hockney & 1937 & 32 \\
\hline Thiebaud & 1920 & 66 & Mangold & 1937 & 52 \\
\hline Olitski & 1922 & 38 & Poons & 1937 & 24 \\
\hline Francis & 1923 & 27 & & & \\
\hline \hline
\end{tabular}

Source: Calculated from regressions reported in appendix. 
before they reached $40 . .^{10}$

This contrast between the generations appears even greater when considered within the context of the artists' careers. This is because several of the first generation of artists considered here died at early ages. So for example Arshile Gorky's most valuable work was done at 43 , just one year before his death, while Franz Kline's age-price profile peaked just four years before his death at 52 . To show these relationships more fully, Figures 1-31 present the full age-price profiles implied by the regression estimates for all the artists for whom age was found to have significantly affected price. For each artist, the relevant figure traces out the hypothetical auction prices of a series of paintings, of identical size, done in each year of the artist's career. ${ }^{11}$ Each profile is bounded by the minimum and maximum ages from which works by the artist appear in the sample analyzed here.

The difference in the careers of the artists born before and after 1920 appears clearly in the figures. With the exception only of Willem de Kooning, the value

\footnotetext{
${ }^{10}$ This conclusion omits the 11 artists for whom age did not have a statistically significant effect on price. Six of these - Albers, Gottlieb, Jensen, Newman, Still, and Tobey - were born before 1920, while five - Diebenkorn, Dine, Marden, Mitchell, and Ryman - were born after 1920. Ignoring the statistical insignificance of the age effects, 5 of the 6 born before 1920 had estimated peak values at age 40 and above, while 3 of the 5 born after 1920 had estimated peaks below 40. Notwithstanding the weakness of the impact of the measured effect of age on price for these artists, the age effects estimated for them are therefore not inconsistent with those of their contemporaries listed in Table 2.

${ }^{11}$ All values in the figures were calculated for paintings on canvas, 24"x 24", sold in 1990-94, in constant (1983) dollars.
} 
of the work of artists born through 1920 rises with age for most or all of their careers. $^{12}$ In this group only one artist, Wayne Thiebaud, remains alive today; for 12 of the other 13, the estimated peak value of their work occurred within ten years of their death. In contrast, the value of the work of most of the artists born after 1920 declines with age during the greater part of their careers. For only one artist, Robert Mangold, does the peak value of his work occur within ten years of the oldest age represented in the auction sample. Since all but three of the artists born after 1920 are still alive, it would still be possible for them to produce new work that would cause their peak value to shift to an older age. Yet even if this occurred, in general it would not make their age-price profiles resemble those of their earlier counterparts, because a late peak alone would not change the fact that the value of their work declines for much of their earlier careers.

\section{Market Values and Critical Evaluation}

The econometric results thus provide strong evidence of a shift over time in the

\footnotetext{
${ }^{12}$ Although this conclusion is drawn from an analysis that holds constant the size of paintings, for many of the artists listed in Table 2 the size of their works changed systematically with their age. There was a statistically significant correlation between painting size and the artist's age in the auction sample for nine of the artists born before 1920, and in each case this correlation was positive. Thus for Hofmann, Rothko, Gorky, Kline, Baziotes, Pollock, Guston, and Motherwell the average value of their paintings increased more with age than is shown in the respective figures, while the average value of de Kooning's paintings decreased less with age than is shown in Figure 5. For a discussion of the increasing size of these artists' paintings over time, see William C. Seitz, Abstract-Expressionist Painting in America (unpublished Ph.D. dissertation, Princeton University, 1955), pp. 231-43. There was a statistically significant and positive correlation for five of the artists in Table 2 who were born after 1920 - Kelly, Lichtenstein, Rivers, Noland, and Rauschenberg - while for two artists - Olitski and Poons - the correlation was significant and negative.
} 
market valuation of artists' work over the course of their careers: whereas the most valuable work of the contemporary artists born before 1920 was usually that done late in their careers, for artists born in the 1920s and ' 30 s their most valuable work is typically that done early in their careers. These results emerge clearly from analysis of sales at art auctions held since 1980. Yet art auctions - particularly those of contemporary art - have sometimes been dismissed by art critics as having little relevance to art appreciation, with prices determined by wealthy collectors whose purchases are of little scholarly interest. Before attempting to interpret the econometric results, a salient question therefore concerns whether they represent the outcomes of decisions based on sophisticated judgments. ${ }^{13}$ One way to answer this question is to compare the age-price profiles estimated above with the evaluations of art experts.

Systematic evidence on scholars' evaluations of the relative quality of artists' work throughout their careers in the form of direct statements is elusive, because for many artists this question has not been addressed explicitly, and even when it has, critics' judgments can be elliptical. Yet unambiguous evidence of these critical evaluations is available in a variety of forms. Two of these will be examined here. The first provides evidence of scholars' judgments of when an artist's most

\footnotetext{
${ }^{13}$ For a general discussion of the relation between aesthetic and market valuations of paintings, see William D. Grampp, Pricing the Priceless: Art, Artists, and Economics (New York: Basic Books, 1989), Chapter 1.
} 
important work was done, while the second reveals critical evaluations of the relative importance of all the stages of an artist's career.

Evidence of critics' judgments of the timing of the most important stage of an artist's career can be drawn from published surveys of contemporary art. Whether monographs or textbooks, these books contain photographs of the work of the leading artists, chosen to illustrate each artist's most important contribution. Although no single book can be considered definitive, examining several popular books can provide a survey of critical opinion, and indicate whether there is a consensus on the best period of each artist's career.

Table 3 lists the ages at which the artists considered in this study executed the paintings reproduced in six important surveys of American art. ${ }^{14}$ Comparing these to the ages at which the artists' work peaked in value is obviously somewhat simplistic, for it does not take into account cases in which an artist did important work at several different stages of his career. Figure 11, for example, indicates that Philip Guston's most valuable paintings are the figurative works done late in his career, after the age of 55, and two of the paintings reproduced by Ashton

\footnotetext{
${ }^{14}$ One book included in Table 4, Henry Geldzahler, New York Painting and Sculpture: $1940-$ 1970 (New York: E. P. Dutton, 1969), is neither a text nor a monograph, but is instead an exhibition catalogue. It is included because this show was a particularly important one, the first major exhibit organized by the Metropolitan Museum's new Department of Contemporary Art, planned to celebrate the museum's centennial. One art critic described it as Henry Geldzahler's "opportunity to define a canon;" Carter Ratcliff, The Fate of a Gesture: Jackson Pollock and Postwar American Art (New York: Farrar, Straus, Giroux, 1996), p. 229.
} 


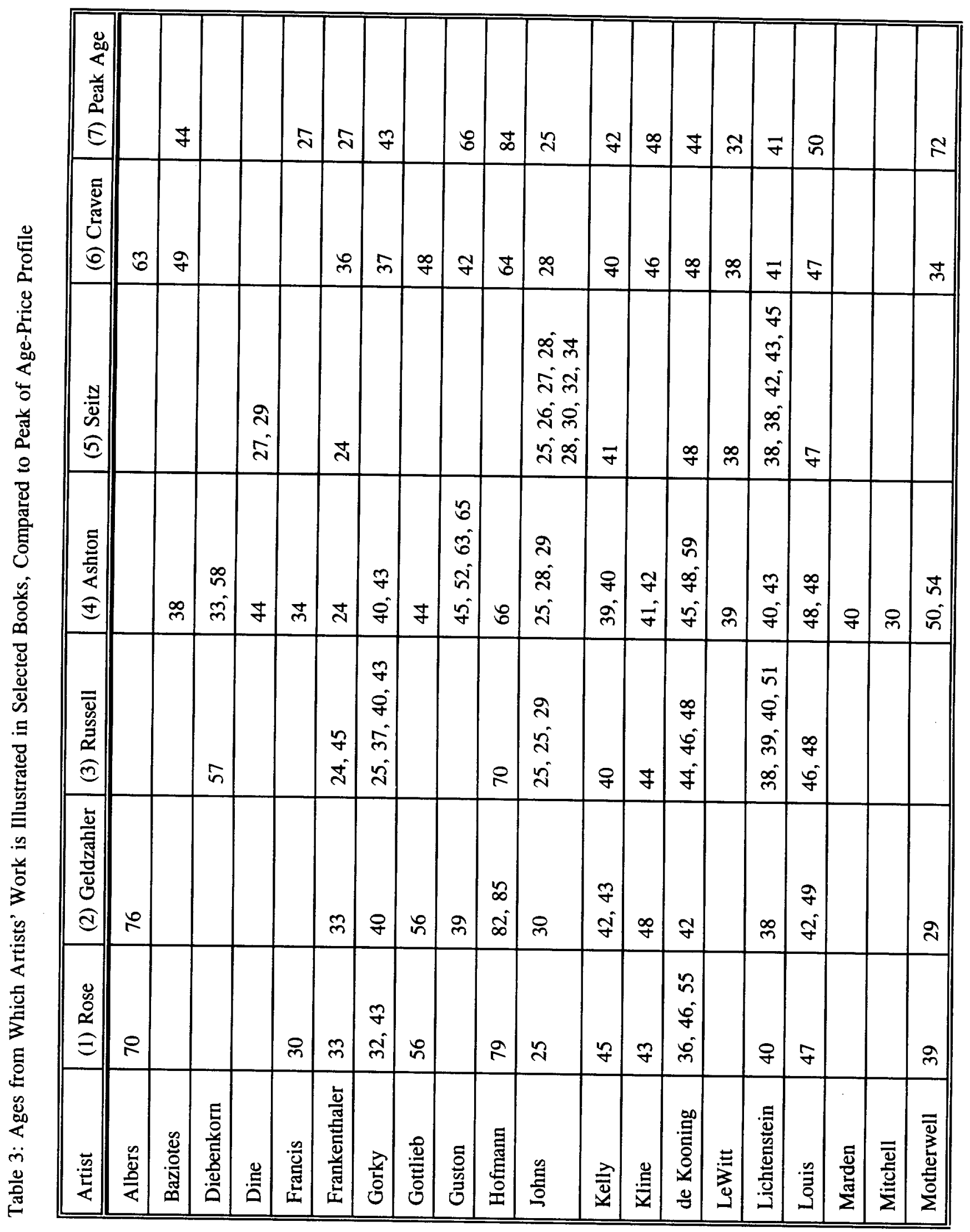




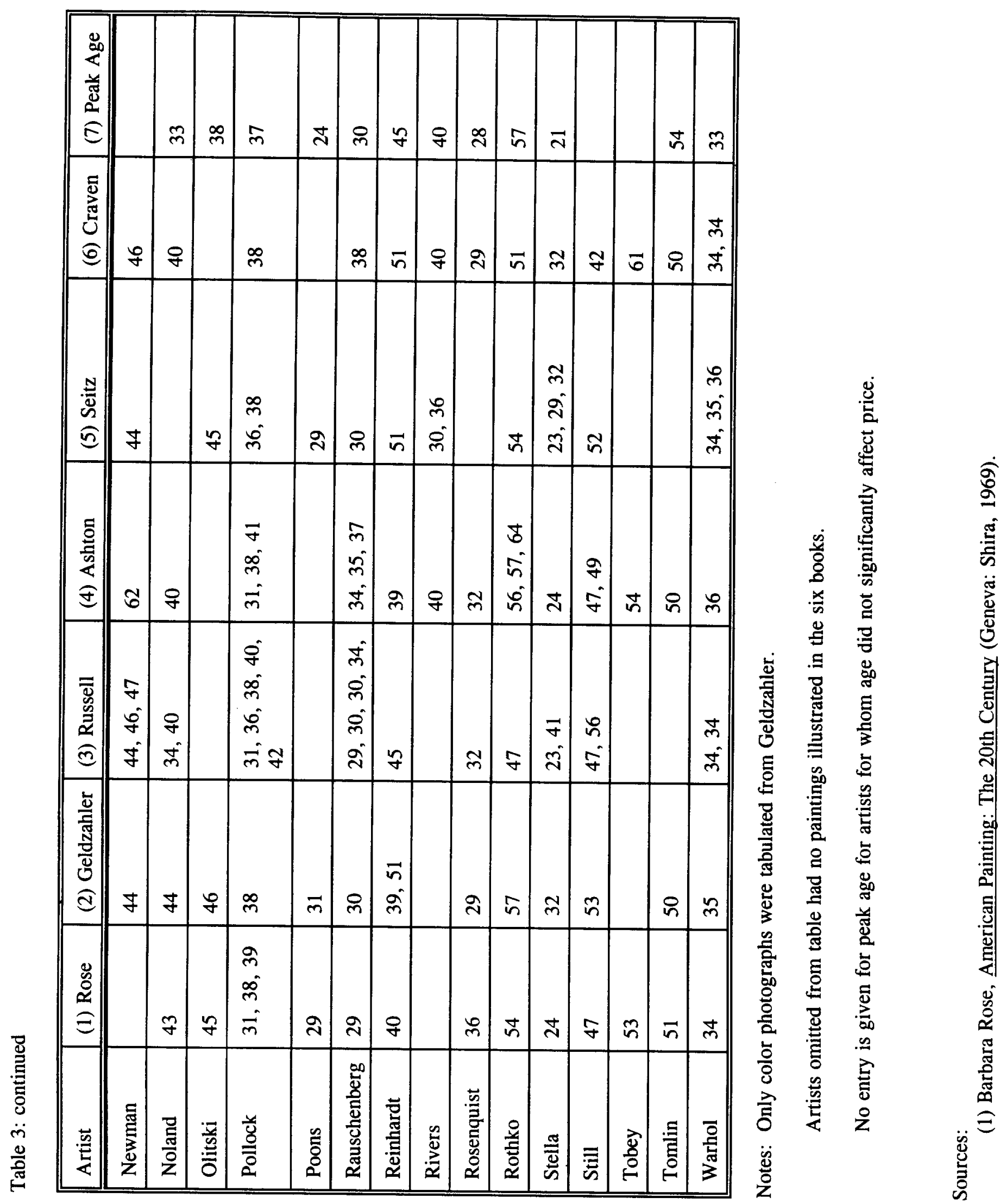


Table 3: continued

(2) Henry Geldzahler, New York Painting and Sculpture: 1940-1970 (New York: E. P. Dutton, 1969).

(3) John Russell, The Meanings of Modern Art (New York: Harper and Row, 1981).

(4) Dore Ashton, American Art Since 1945 (New York: Oxford University Press, 1982).

(5) William C. Seitz, Art in the Age of Aquarius, 1955-1970 (Washington: Smithsonian Institute, 1992).

(6) Wayne Craven, American Art: History and Culture (New York: Abrams, 1994).

(7) Table 2, above. 
are from this period. ${ }^{15}$ But three of the illustrations of Guston's work listed in Table 3 are of paintings done in his late $30 \mathrm{~s}$ and $40 \mathrm{~s}$, when he was "considered the exemplar of Abstract Impressionism," and a fourth, done at age 52, is shown by Ashton to document his evolution toward a new style. ${ }^{16}$ In spite of cases like this, however, in general the ages at which artists' work is illustrated in the texts summarized in Table 3 correspond quite closely to the ages at which the artists' work peaked in value. In total, the six books analyzed contain 192 photographs of paintings by 26 artists for whom peaks of age-price profiles are shown in Table 2. Of these illustrated paintings, $122(69 \%)$ were done within five years of the peak ages shown in Table 2, and $159(88 \%)$ were done within ten years of those peak ages.

The correspondence between the two types of evidence is striking for a number of artists. ${ }^{17}$ The artist with the most works illustrated in the six books is Jasper Johns. Five of the 17 illustrations of his work show paintings done at the age of 25 , the estimated peak of his age-price profile; another eight are of paintings done later in his $20 \mathrm{~s}$, and the remaining four are of paintings he did between 30

\footnotetext{
${ }^{15}$ Musa Mayer, Night Studio: A Memoir of Philip Guston (New York: Da Capo Press, 1997), pp. 148-59.

${ }^{16}$ Sandler, The New York School, p. 55; Dore Ashton, American Art Since 1945 (New York: Oxford University Press, 1982), pp. 99-102.

${ }^{17}$ Artists for whom the entries in Table 3 cluster closely together are obviously those for whom there is a critical consensus that the the artist's most important work was done at a particular time.
} 
and 34. None of the 15 illustrations of paintings by Jackson Pollock was done more than six years from the age of 37 , at which the value of his work peaked; six of the 15 are of paintings done within one year of that age. The 10 illustrations for Andy Warhol were all of paintings done between ages 34 and 36, all within three years of his estimated age of peak value at 33 . Thirteen of the 14 paintings by Roy Lichtenstein illustrated in the books were done between 38 and 45 , none of these more than four years from his estimated age of peak value at 41 . Eight of the 9 illustrations of paintings by Morris Louis are of work done within five years of his estimated peak age, as are nine of the 11 illustrations for Robert Rauschenberg, and all eight illustrations for Ellsworth Kelly. For only one artist, Robert Motherwell, does none of the illustrations show paintings done near the age at which his work peaked in value.

For most of the artists, the illustrations of the texts therefore suggest that critics' judgments of the timing of their best work coincides quite closely with the evaluation of the market. Of the 31 artists listed in Table 2 - those for whom age significantly affected the auction value of their work - 26 have work reproduced in the six books considered here. For 18 of these 26, half or more of the illustrations are of work done within five years of the age at which their paintings peaked in value, and for 18 all of the paintings illustrated were done within 10 years of that estimated peak age. 
In contrast to textbook illustrations, which are usually chosen to represent the author's judgment of an artist's single best period, systematic critical evaluations of the relative quality of artists' work over the course of their entire careers are implicit in the composition of retrospective exhibitions. Curators who organize retrospectives reveal their judgments of the importance of an artist's work at different ages through their decisions on how many paintings to include from each phase of the artist's career. Some exhibitions might not precisely reflect an organizer's wishes, because inability to locate some works, or to persuade owners to lend valuable works, can prevent the inclusion of paintings the organizer would have liked to show. Yet this effect is likely to be minor for retrospectives produced by important museums, for these institutions devote substantial resources to finding and obtaining the works they consider important, and the prestige and value of the imprimatur conferred on paintings included in these shows increases the likelihood that owners will agree to lend their paintings. In addition, although retrospectives are typically organized by a single museum, after they have been shown at that site most tour to two or three other museums. This means that the curators who organize these exhibitions can usually draw on the efforts and influence of their counterparts at several other important museums in assembling the shows.

Table 4 shows the age distributions of paintings included in retrospective ex- 
hibitions of artists included in this study. The distinction of the artists considered makes it possible to find catalogues of retrospectives held by major museums for most; of the 35 exhibitions summarized in Table 4, 16 were presented in New York at either the Museum of Modern Art or the Whitney Museum, the two leading American museums devoted exclusively to modern art, while another 12 were shown at the Metropolitan Museum, the National Gallery, the Guggenheim Museum, or Boston's Museum of Fine Arts.

The agreement between the auction market valuations and the critical evaluations of the retrospectives as to when artists did their best work is generally impressive. Figure 4 shows that the age-price profile for Arshile Gorky, for example, is highest in the final years of his life. The Museum of Modern Art retrospective for Gorky had an average of more than 12 paintings per year from the final five years of his life, a figure more than triple that for any earlier period in his career. Jackson Pollock's age-price profile, shown in Figure 10, peaks at 37, then declines to his death at 44; the Museum of Modern Art retrospective for him had the most paintings per year from his late 30s, considerably more than from any earlier period, and more than from his early 40s. As discussed earlier, Philip Guston's late work produced the greatest values at auction; the Whitney retrospective of his work included more than twice as many paintings per year from his final decade as from any earlier stage of his career. Willem de 


\begin{tabular}{|c|c|c|c|c|c|c|c|c|c|c|c|c|c|c|c|c|c|c|c|c|c|c|}
\hline $\begin{array}{l}a \\
\vdots \\
\infty\end{array}$ & $\stackrel{m}{0}$ & & & & & & & & & & $\stackrel{\circ}{r}$ & & & & & & & & & & & \\
\hline $\begin{array}{l} \pm \\
0\end{array}$ & $\stackrel{\sim}{m}$ & & & & & & & & & & $\stackrel{\dot{m}}{\dot{\theta}}$ & & & & & $\stackrel{\infty}{0}$ & & & & & & \\
\hline ì & $\stackrel{\sim}{m}$ & & & & & & & & & & $\stackrel{\circ}{\circ}$ & $\stackrel{0}{-}$ & & & & $\stackrel{\Upsilon}{\dddot{N}}$ & & & & & & \\
\hline$\stackrel{+}{\stackrel{1}{2}}$ & $\stackrel{\text { Iִ }}{-}$ & & & & & & & $\stackrel{\theta}{m}$ & & & $\stackrel{0}{-}$ & $\stackrel{0}{\circ}$ & & $\stackrel{\circ}{\circ}$ & & $\underset{\sim}{\stackrel{\circ}{\sim}}$ & & & & & & \\
\hline$\vec{b}$ & $\stackrel{\infty}{0}$ & & & & $\vec{i}$ & & & $\begin{array}{l}\infty \\
\dot{m}\end{array}$ & $\stackrel{n}{r}$ & & . & $\stackrel{0}{-}$ & $\stackrel{0}{\circ}$ & ํ. & & $\stackrel{\Im}{-}$ & & $\stackrel{8}{\forall}$ & & & & \\
\hline $\begin{array}{l} \pm \\
\text { Iे }\end{array}$ & $\stackrel{y}{m}$ & & & & $\underset{\gamma}{\sim}$ & $\stackrel{0}{\circ}$ & & $\stackrel{+}{-}$ & $\begin{array}{l}\forall \\
\text { in }\end{array}$ & & $\stackrel{\infty}{\longrightarrow}$ & $\stackrel{\circ}{\circ}$ & $\stackrel{\Delta}{\sim}$ & $\stackrel{0}{-}$ & & I & $\underset{\infty}{+}$ & $\stackrel{\infty}{\text {. }}$ & & & & $\tilde{\sim}$ \\
\hline $\begin{array}{l}a \\
n \\
n\end{array}$ & $\stackrel{\sim}{\sim}$ & & $\ddot{n}$ & & $\stackrel{+}{-}$ & $\stackrel{0}{0}$ & & ָָ & $\stackrel{\sim}{\sim}$ & & $\underset{\sim}{\stackrel{0}{N}}$ & $\underset{\sim}{\sim}$ & $\stackrel{\circ}{i}$ & $\begin{array}{r}\dot{H} \\
\dot{m}\end{array}$ & & $\stackrel{\sim}{\sim}$ & $\underset{\forall}{+}$ & $\stackrel{\infty}{\sim}$ & & & & Y \\
\hline $\begin{array}{l} \pm \\
8\end{array}$ & ir & $\stackrel{\circ}{i}$ & 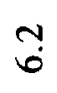 & & $\stackrel{+}{-}$ & $\stackrel{\circ}{-}$ & & $\begin{array}{l}0 \\
i\end{array}$ & $\stackrel{0}{-}$ & & 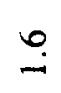 & $\stackrel{\nabla}{\square}$ & $\stackrel{\ddot{m}}{\ddot{m}}$ & $\underset{\sim}{\sim}$ & $\stackrel{\circ}{\stackrel{0}{0}}$ & $\stackrel{\infty}{\sim}$ & $\underset{\infty}{N}$ & $\begin{array}{l}\infty \\
\dot{m}\end{array}$ & $\stackrel{\circ}{\circ}$ & & & $\stackrel{\sim}{\sim}$ \\
\hline aे & $\stackrel{\circ}{\circ}$ & $\stackrel{\circ}{i}$ & $\underset{0}{0}$ & & $\stackrel{\circ}{\longrightarrow}$ & $\stackrel{0}{-}$ & & $\stackrel{\circ}{\circ}$ & $\stackrel{0}{-}$ & $\begin{array}{l}0 \\
\dot{n}\end{array}$ & $\stackrel{\Perp}{\longrightarrow}$ & & $\stackrel{\nabla}{\sim}$ & ウे. & $\dot{m}$ & $\stackrel{\nabla}{m}$ & $\begin{array}{l}0 \\
\end{array}$ & $\stackrel{\infty}{m}$ & $\stackrel{\sim}{n}$ & & & $\stackrel{\infty}{\forall}$ \\
\hline $\begin{array}{l}\dot{y} \\
\text { Oे }\end{array}$ & $\stackrel{\sim}{n}$ & $\begin{array}{l}\infty \\
\sim \\
ن\end{array}$ & $\begin{array}{l}\dot{\varphi} \\
\dot{n}\end{array}$ & & $\stackrel{\infty}{m}$ & $\stackrel{\infty}{0}$ & $\stackrel{\nabla}{\sim}$ & $\stackrel{\circ}{\circ}$ & $\stackrel{0}{\longrightarrow}$ & $\stackrel{\sim}{r}$ & $\stackrel{\sim}{0}$ & & $\stackrel{\text { ִ }}{3}$ & $\stackrel{\vec{c}}{\sim}$ & $\stackrel{\infty}{\infty}$ & $\stackrel{\sim}{\sim}$ & $\frac{6}{N}$ & $\underset{\infty}{\Delta}$ & $\stackrel{0}{\sim}$ & & & $\stackrel{\sim}{m}$ \\
\hline ì & $\stackrel{\nabla}{-}$ & $\stackrel{\infty}{\sim}$ & $\stackrel{\infty}{\forall}$ & & $\begin{array}{l}0 \\
\dot{n}\end{array}$ & $\stackrel{\circ}{-}$ & $\stackrel{\circ}{\circ}$ & $\stackrel{\circ}{\forall}$ & $\stackrel{\infty}{-}$ & $\stackrel{\nabla}{\sim}$ & $\ddot{\sigma}$ & & $\stackrel{\forall}{\sim}$ & $\begin{array}{l}\infty \\
m\end{array}$ & $\stackrel{Y}{\forall}$ & $\stackrel{0}{0}$ & $\stackrel{0}{r}$ & $\begin{array}{l}\infty \\
0\end{array}$ & $\stackrel{\infty}{0}$ & & & $\stackrel{\nabla}{\sim}$ \\
\hline ఫ্ল & 0 & $\stackrel{0}{0}$ & $\dot{v}$ & & $\stackrel{\sim}{n}$ & $\stackrel{0}{-}$ & $\stackrel{r}{m}$ & $\stackrel{0}{0}$ & $\stackrel{N}{-}$ & $\stackrel{\circ}{\circ}$ & $\stackrel{0}{-}$ & & ֶָ & $\stackrel{\circ}{\dot{*}}$ & $\underset{\sim}{\sim}$ & $\stackrel{\sim}{0}$ & $\underset{\infty}{\infty}$ & 0 & 0 & & & $\stackrel{\nabla}{\sim}$ \\
\hline ì & $\ddot{0}$ & & $\stackrel{\vec{i}}{\sim}$ & & $\stackrel{\sim}{*}$ & $\stackrel{\nabla}{\circ}$ & $\stackrel{\sim}{\text { ָे }}$ & $\stackrel{0}{-}$ & $\begin{array}{l}0 \\
0\end{array}$ & ֶָ. & 0 & & $\begin{array}{l}0 \\
0\end{array}$ & $\stackrel{t}{0}$ & $\stackrel{\infty}{0}$ & & & $\stackrel{\nabla}{0}$ & ָ̊ & & & $\stackrel{0}{\longrightarrow}$ \\
\hline 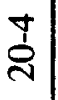 & & & $\stackrel{\sim}{0}$ & & $\stackrel{\forall}{0}$ & $\stackrel{\sim}{0}$ & I & $\stackrel{\circ}{-}$ & $\stackrel{\sim}{0}$ & $\underset{\sim}{\sim}$ & $\stackrel{0}{0}$ & & $\stackrel{\nabla}{0}$ & $\stackrel{\sim}{0}$ & & & & & & & & $\stackrel{1}{0}$ \\
\hline$\frac{a}{a}$ & & & & & & & $\stackrel{\Upsilon}{0}$ & & $\stackrel{\Delta}{0}$ & $\stackrel{\nabla}{0}$ & $\stackrel{0}{-}$ & & & & & & & & & & & $\stackrel{\sim}{0}$ \\
\hline 绨 & $\frac{\mathscr{D}}{\frac{\Phi}{q}}$ & 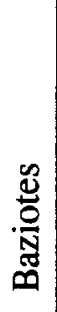 & 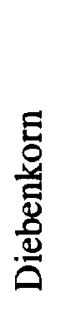 & $\stackrel{\mathscr{E}}{\stackrel{\Xi}{\omega}}$ & 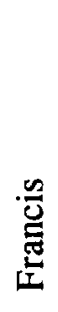 & 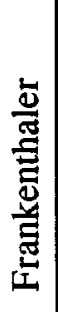 & $\begin{array}{l}\widehat{y} \\
0 \\
0\end{array}$ & 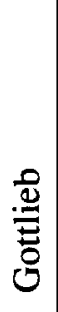 & $\begin{array}{l}\bar{\sigma} \\
\frac{0}{0} \\
\tilde{\Xi}\end{array}$ & 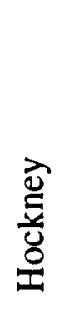 & 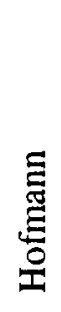 & 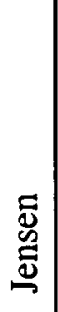 & 疍 & $\frac{\grave{\bar{d}}}{\square}$ & $\stackrel{\mathscr{\Xi}}{\Xi}$ & 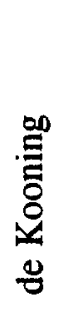 & 売 & 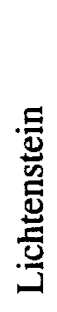 & 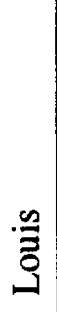 & 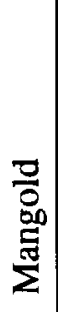 & $\begin{array}{l}\text { Dี } \\
\frac{D}{5} \\
\sum\end{array}$ & 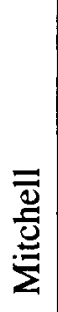 \\
\hline
\end{tabular}




\begin{tabular}{|c|c|c|c|c|c|c|c|c|c|c|c|}
\hline$\stackrel{1}{\infty}$ & & & & & & & & & & & \\
\hline$\vec{\Delta}$ & & & & & & & & & $\because$ & & \\
\hline : & & & & & & & & & $=$ & & \\
\hline है & & & & & & & 1 & 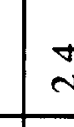 & 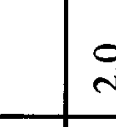 & 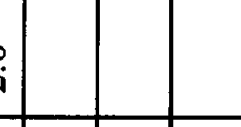 & \\
\hline : & नि: & & & $\stackrel{\infty}{=}$ & & & $\stackrel{1}{=}$ & : & 2 & $\stackrel{\infty}{\infty}$ & \\
\hline 是 & $\pi \%$ & & & $:$ & & & \pm & & $\left.\begin{array}{l}\infty \\
\vdots \\
\vdots\end{array}\right]$ & 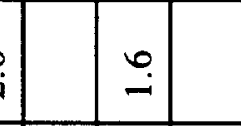 & \\
\hline$\stackrel{0}{\circ}$ & $7 \pi$ & & & $:$ & & i. & نี & $\cong$ & 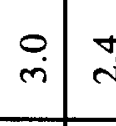 & $\because \cong$ & \\
\hline 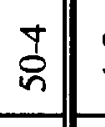 & $\stackrel{\infty}{\because}: \infty$ & $=\Xi$ & & $\because$ & 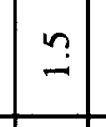 & & 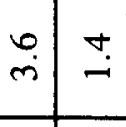 & & $\approx$ & 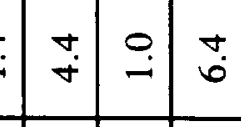 & \\
\hline$\frac{q}{q}$ & 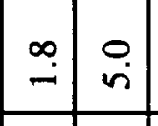 & 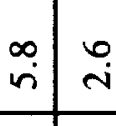 & & - & $\underset{-}{-\infty}$ & & 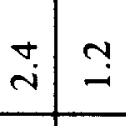 & $\cong$ & 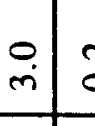 & $0: 0$ & \\
\hline 孝 & $|\stackrel{ن}{ن}| \begin{array}{l}: \\
\because\end{array}$ & & $\stackrel{\circ}{\circ}$ & $\doteq$ & $\div$ & & $\sqrt[7]{4}$ & & ت. & $\exists \square$ & \\
\hline 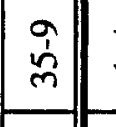 & & & 姜 & 잉 & : & & 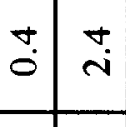 & $\therefore$ & & 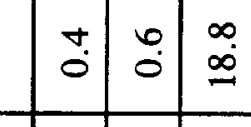 & \\
\hline 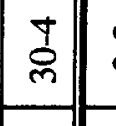 & & & 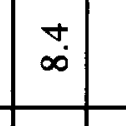 & : & & & 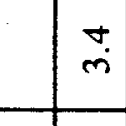 & & & $: \infty 0^{\infty}$ & \\
\hline$\dot{a}$ & & & $\stackrel{-1}{\circ}$ & $\circ$ & \pm & & $\stackrel{\circ}{i}$ & & & 8 & \\
\hline \& & & & \pm & : & & & 1 & & & $\because:$ & \\
\hline 尝| & & & & & & & 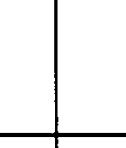 & & & & \\
\hline & & & & & & & & & & & \\
\hline
\end{tabular}


Table 4: continued

For Gottlieb: graphics and postcards are excluded.

For Hockney: lithographs, photographs, etchings, and photo collages are excluded.

For Jensen: sketchbooks are excluded.

For Johns: drawings, prints, and sculptures are excluded.

For Kelly: photographs are excluded.

For Lichtenstein: lithographs, screenprints, photographs, schulptures, and murals are excluded.

For Newman: sculpture, works on paper, and architecture are excluded.

For Pollock: prints are excluded.

For Twombly: sculptures are excluded.

Sources:

Diane Waldman, Josef Albers: A Retrospective (New York: Solomon R. Guggenheim Museum, 1988).

Lawrence Alloway, William Baziotes: A Memorial Exhibition (New York: Solomon R.

Guggenheim Foundation, 1965).

Robert T. Buck, Richard Diebenkorn: Paintings and Drawings, 1943-1980 (Buffalo: Albright-

Knox Art Gallery, 1980).

Pontus Hulten, Sam Francis (Bonn: Edition Cantz, 1993).

E. A. Carmean, Jr., Helen Frankenthaler: A Paintings Retrospective (New York: Harry N. Abrams, 1989).

William C. Seitz, Arshile Gorky (New York: Doubleday, 1962).

Lawrence Alloway and Mary Davis MacNaughton, Adolph Gottlieb: A Retrospective (New

York: Arts Publisher, 1981).

Henry T. Hopkins, Philip Guston (New York: George Braziller, 1980).

Maurice Tuchman and Stephanie Barron, David Hockney: a Retrospective (Los Angeles: Los

Angeles County Museum of Art, 1988).

Cynthia Goodman, Hans Hofmann (Munich: Prostel-Verlag, 1990).

Thomas M. Messer, Alfred Jensen: Paintings and Works on Paper (New York: Solomon R.

Guggenheim Museum, 1985).

Kirk Varnedoe, Jasper Johns: A Retrospective (New York: Museum of Modern Art, 1996).

Diane Waldman, Ellsworth Kelly: A Retrospective (New York: Guggenheim Museum, 1996).

John Gordon, Franz Kline, 1910-1962 (New York: Whitney Museum, 1968).

Marla Prather, Willem de Kooning (New Haven: Yale University Press, 1994).

Susanna Singer, Sol LeWitt Drawings, 1958-1992 (The Hague: Haags Gemeentemuseum, 1992).

Diane Waldman, Roy Lichtenstein (New York: Guggenheim Museum, 1993).

Michael Fried, Morris Louis, 1912-1962 (Boston: Museum of Fine Arts, 1967).

Judith E. Bernstock, Joan Mitchell (New York: Hudson Hills Press, 1988).

Robert T. Buck, Robert Motherwell (New York: Abbeville Press, 1983).

Thomas B. Hess, Barnett Newman (New York: Museum of Modern Art, 1971).

Diane Waldman, Kenneth Noland: A Retrospective (New York: Solomon R. Guggenheim Foundation, 1977).

Kenworth Moffett, Jules Olitski (Boston: Museum of Fine Arts, 1973).

Francis V. O'Connor, Jackson Pollock (New York: Museum of Modern Art, 1967).

Kenworth Moffett, Fairfield Porter (1907-1975) (Boston: Museum of Fine Arts, 1982). 
Table 4: continued

Yve-Alain Bois, Ad Reinhardt (New York: Rizzoli, 1991).

Carl Haenlien, Larry Rivers: Retrospektive (Hannover: Kestner-Gesellschaft, 1980).

R. H. van den Brande, Mark Rothko (Rotterdam: Museum Boymans-van Beuningen, 1971). Robert Storr, Robert Ryman (London: Tate Gallery, 1993).

John P. O'Neill, Clyfford Still (New York: Metropolitan Museum of Art, 1979).

Karen Tsujimoto, Wayne Thiebaud (Seattle: University of Washington Press, 1985).

Adelyn D. Breeskin, Tribute to Mark Tobey (Washington, D.C.: Smithsonian Institution

Press, 1974).

John I. H. Baur, Bradley Walker Tomlin (New York: Macmillan, 1957).

Kirk Varnedoe, Cy Twombly: A Retrospective (New York: Museum of Modern Art, 1994). 1989).

Kynaston McShine, Andy Warhol: A Retrospective (New York: Museum of Modern Art, 
Kooning's age-price profile, shown in Figure 5, peaks at 44; his National Gallery retrospective, which spanned 48 years, placed its heaviest emphasis on ages 45-9. Figure 1 shows that Hans Hofmann's age-price profile rises through his 70s, and peaks at 84 ; his Whitney retrospective, which spanned 67 years of his career, had far more paintings from his late 70s than from any earlier period, followed by an even larger number of paintings per year from his 80 s.

The subtlety of the relationship between the auction valuations and the composition of retrospectives is illustrated by the case of Jasper Johns. From the evidence of Table 4, the composition of Johns' recent Museum of Modern Art retrospective seems to conflict somewhat with the value of his work by age shown in Figure 26: the retrospective did have the largest number of paintings per year from his late $20 \mathrm{~s}$, as the age-price profile would suggest, but the retrospective also had nearly as many paintings from his early 30 s, in spite of sharply lower prices. Yet this apparent disagreement is in large part a result of the age categorization of Table 4 . The annual series in Table 5 show that the retrospective reflected the age-price profile quite closely, tracking both its peaks and its troughs. ${ }^{18}$ Overall, Johns' retrospective included a total of 127 paintings from 42 years of his career, an average of 3 paintings per year. Table 5 shows that the ten years of Johns' career with the highest estimated prices were those from ages 25-30 and 52-55,

\footnotetext{
${ }^{18}$ The correlation between the two series in Table 5 is .51 , significant at the .001 level.
} 
Table 5: Annual Estimated Prices for Jasper Johns and Annual Composition of His Retrospective

\begin{tabular}{|c|c|c|c|c|c|c|c|}
\hline Year & Age & Price & $\begin{array}{l}\text { Paintings } \\
\text { (n) }\end{array}$ & Year & Age & Price & $\begin{array}{l}\text { Paintings } \\
\text { (n) }\end{array}$ \\
\hline 1954 & 24 & n.a. & 2 & 1975 & 45 & 12.42 & 4 \\
\hline 55 & 25 & 14.90 & 8 & 76 & 46 & 12.49 & 0 \\
\hline 56 & 26 & 14.44 & 2 & 77 & 47 & 12.56 & 0 \\
\hline 57 & 27 & 14.02 & 5 & 78 & 48 & 12.64 & 2 \\
\hline 58 & 28 & 13.66 & 9 & 79 & 49 & 12.70 & 1 \\
\hline 59 & 29 & 13.34 & 9 & 1980 & 50 & 12.76 & 2 \\
\hline 1960 & 30 & 13.06 & 5 & 81 & 51 & 12.81 & 4 \\
\hline 61 & 31 & 12.83 & 8 & 82 & 52 & 12.84 & 2 \\
\hline 62 & 32 & 12.63 & 9 & 83 & 53 & 12.86 & 4 \\
\hline 63 & 33 & 12.47 & 3 & 84 & 54 & 12.87 & 6 \\
\hline 64 & 34 & 12.35 & 6 & 85 & 55 & 12.85 & 2 \\
\hline 65 & 35 & 12.25 & 1 & 86 & 56 & 12.81 & 4 \\
\hline 66 & 36 & 12.18 & 2 & 87 & 57 & 12.74 & 1 \\
\hline 67 & 37 & 12.14 & 2 & 88 & 58 & 12.65 & 2 \\
\hline 68 & 38 & 12.12 & 2 & 89 & 59 & 12.52 & 1 \\
\hline 69 & 39 & 12.12 & 0 & 1990 & 60 & 12.36 & 3 \\
\hline 1970 & 40 & 12.14 & 0 & 91 & 61 & 12.17 & 3 \\
\hline 71 & 41 & 12.18 & 3 & 92 & 62 & n.a. & 1 \\
\hline 72 & 42 & 12.22 & 1 & 93 & 63 & n.a. & 3 \\
\hline 73 & 43 & 12.28 & 0 & 94 & 64 & n.a. & 2 \\
\hline 74 & 44 & 12.35 & 2 & 95 & 65 & n.a. & 1 \\
\hline
\end{tabular}

Notes: $\quad$ n.a. $=$ not available

Price $=$ natural logarithm of price for painting on canvas, $24 " \times 24 "$, sold in 1990-94, in constant (1983) dollars; calculated from Appendix.

Paintings $=$ number of paintings from each year included in Jasper Johns retrospective. See Kirk Varnedoe, Jasper Johns: A Retrospective (New York: Museum of Modern Art, 1996), pp. 404-05. 
and that the retrospective included a total of 52 paintings from these years. In contrast, the ten years with the lowest estimated prices - ages 35-43 and 61.were represented by a total of only 14 paintings. Whereas the ten years with the highest estimated prices accounted for six of the nine years from which the retrospective had 5 or more paintings, the ten years with the lowest prices accounted for none of these nine years; the ten years with the lowest prices did, however, include three of the five years of Johns' career from which there were no paintings in the retrospective.

In short, for nearly all the artists considered here for whom age was found to have a significant effect on the market value of their work and for whom catalogues of retrospectives are available, the evidence from the two sources on when the artists did their best work appears consistent. For some artists - those discussed above, as well as Baziotes, Francis, Kline, Louis, Rivers, Rothko, Thiebaud, Tomlin, Twombly, and Warhol - the agreement between the two sources is strong, with heavy emphasis by the retrospectives on the period of peak market value. In a few cases, notably those of Frankenthaler, Kelly, LeWitt, and Olitski, the greatest emphasis of the retrospectives is not on the most highly priced period of the artist's career. ${ }^{19}$ Yet rarely is there strong disagreement between the two sources:

\footnotetext{
${ }^{19}$ For living artists, disagreement between auction valuations and retrospectives can result from the time lag between the execution of paintings and their appearance at auction. So for example the LeWitt retrospective summarized in Table 4 gives considerable emphasis to works
} 
only for Robert Motherwell does the retrospective give its greatest emphasis to a period far from that most highly valued by the auction market.

Overall, the conclusion drawn from the evidence of the retrospectives therefore reinforces that taken from the earlier consideration of the monographs and textbooks, that the auction market produces valuations of work over the course of artists' careers very similar to the evaluations of scholars. This heightens the interest in explaining the patterns produced by the age-price profiles, particularly the striking contrast between the typically rising value of paintings with age for artists born before 1920 and the opposite relationship for artists born after that date.

\section{Changes in Artists' Careers: An Explanation}

The shift described above in the careers of contemporary artists has not previously been discussed or systematically analyzed. The statistical evidence of the shift is surprising both for its consistency across artists and for its abruptness: a large number of artists born before 1920 exhibit the pattern of rising values to a peak late in their career, while a similarly large number born after 1920 show the opposite pattern of an early peak and subsequently falling values. A detailed

done at ages 60-4, i.e. executed during 1988-92. Of the 93 works by LeWitt in the auction sample, only 6 date from 1988 or later. The underrepresentation of recent work in auctions can therefore potentially result in a failure of the auction prices to reflect the latest developments in a living artist's career. When a living artist cooperates in arranging a retrospective, the opportunity to present new work that is not familiar to the public might also lead curators to give a greater emphasis to the artist's latest work. 
explanation of a change involving so many artists would require systematic study of biographies, and lies beyond the scope of this study. Yet some central elements of an explanation, having to do with changes over time in the nature of painting and in the market conditions facing artists, can be provided. For the most part these can be drawn from the work of art historians and critics.

The explanation begins with the observation that in recent times, the importance of an artist's work has increasingly been judged by that artist's ability to solve formal problems within art. One influential historian, Michael Fried, proposed that "the history of painting from Manet through Synthetic Cubism and Matisse may be characterized in terms of the gradual withdrawal of painting from the task of representing reality ... in favor of an increasing preoccupation with problems intrinsic to painting itself." 20 A key consequence of this was that it now became possible "to conceive of stylistic change in terms of the decisions of individual artists to engage with particular formal problems thrown up by the art of the recent past." 21 A critic who regretted the tendency to use this criterion in evaluating the work of artists remarked in 1968 on its pervasiveness, "how often recent Abstract American painting is defined and described almost exclusively in

\footnotetext{
${ }^{20}$ Michael Fried, Three American Painters (Cambridge: Fogg Art Museum, 1965), p. 5. Fried's statement follows the position taken earlier by Clement Greenberg; e.g. see Greenberg, Arrogant Purpose, 1945-1949 (Chicago: University of Chicago Press, 1986), pp. 221-25; Greenberg, Affirmations and Refusals, pp. 113-19.

${ }^{21}$ Fried, Three American Painters, p. 8.
} 
terms of internal problem-solving. As though the strength of a particular artist expressed itself only in his choice to conform with a set of existent professional needs and his inventiveness in producing the answers." The critic, Leo Steinberg, used technological change as a metaphor: "The dominant formalist critics today tend to treat modern painting as an evolving technology wherein at any one moment specific tasks require solution ... The artist as engineer and research technician becomes important insofar as he comes up with solutions to the right problem." 22

Yet defining problems, and recognizing their solutions, can be more elusive in art than in some other disciplines in which the success or failure of new technologies can be tested more clearly by their results. The formalist critic's solution is in effect to let practitioners identity successful innovations: an artist's influence on others becomes the key evidence of that artist's success in solving technical problems, for "the ultimate criterion of the legitimacy of a putative advance in modernist painting is its fecundity." 23 In consequence, Fried observes, "we are able to make meaningful stylistic discriminations among the painters generally

\footnotetext{
${ }^{22}$ Leo Steinberg, Other Criteria: Conformations with Twentieth-Century Art (London: Oxford University Press, 1972), pp. 77-8. Henry Geldzahler used similar terms in a discussion of the evolution of New York art in the 1950s: "I think one of the ways to look at modernism is as a group research project, the way pure mathematics might be, so that the advances that are made in the field are advances that become available to everybody who's working in it;" quoted in Emile de Antonio and Mitch Tuchman, Painters Painting (New York: Abbeville Press, 1984), p. 79.

${ }^{23}$ Fried, Three American Painters, p. 9.
} 
included under the blanket misnomer Abstract Expressionism only where subsequent modernist painting has directed our attention to various differences among them," and he approvingly quotes historian Meyer Schapiro's conclusion that "the development of new viewpoints and problems in [contemporary art] directs the attention of students to unnoticed features of older styles." ${ }^{24}$ Fried is at pains to emphasize that "the development of modernist painting determines, to a degree that we must be on our guard never to underestimate, our stylistic analyses of the art of the recent past." 25

Devising solutions to formal problems, and having those solutions adopted by other artists, has thus increasingly become the hallmark of success for artists during the past century. And a number of observers have further remarked on the acceleration of this process in the recent past. Fried refers to this in passing, as a "quickening that has taken place in the rate of self-transformation within modernism itself." ${ }^{26}$ But this acceleration, and the associated growth in emphasis on the importance of dramatic innovation for contemporary artists, has received more attention - and been the object of greater concern - from others. So in 1968 the critic Clement Greenberg surveyed the period discussed by Fried, and concluded that "Until the middle of the last century innovation in Western art

\footnotetext{
${ }^{24}$ Fried, Three American Painters, p. 11

${ }^{25}$ Fried, Three American Painters, p. 11.

${ }^{26}$ Fried, Three American Painters, p. 9.
} 
had not had to be startling or upsetting; since then ... it has had to be that. And now in the 60 s it is as though everybody had finally ... caught on not only to the necessity of innovation, but also to the necessity - or seeming necessity - of advertising innovation by making it startling and spectacular." Greenberg noted that producing conspicuous innovations had become a preoccupation of artists: "Today everybody innovates. Deliberately, methodically. And the innovations are deliberately and methodically made startling." 27 Another who remarked on this trend was Henry Geldzahler, the first curator of Contemporary Art at the Metropolitan Museum. He recalled "in the late 1950s being shocked to hear painters, who believed in the primacy of de Kooning's position and who admired him, wondering aloud whether next year's show would repeat his success, whether he could consolidate his lead not by painting a beautiful show but by changing in an unexpected and unpredictable way." Geldzahler attributed this demand for novelty in part to the growing interest in art of the mass media, "with their concern for immediacy and emphasis on the current moment," and in part to the workings of the gallery system. Galleries that catered "to an audience overeager to spot trends, rising reputations, and falls from favor" conceived new shows "more in response to the demands of fashion than art." The "biennial exhibitions of each

\footnotetext{
${ }^{27}$ Greenberg, Modernism with a Vengeance, $1957-1969$ (Chicago: University of Chicago Press, 1993), p. 300.
} 
artist's work" from which the galleries profited created "cruel and destructive" pressure for artists to change their work, leading to the application of "the false urgency of Hollywood to the fine arts." 28

In his description of the gallery system and the growing interest of the mass media, Geldzahler identified a basic way in which the environment facing young American artists changed during the period spanned by the careers of the artists analyzed in this study. The older artists considered here - those born before 1920 - entered a profession in which there was little immediate demand for their work. There were relatively few outlets for the work of American artists during the 1920s, and this situation did not change greatly during the Depression or World War II. ${ }^{29}$ Yet after World War II it did begin to change. The very success of the older artists, led by Jackson Pollock and Willem de Kooning, in establishing the

\footnotetext{
${ }^{28}$ Geldzahler, New York Painting and Sculpture, pp. 28-29.

${ }^{29}$ Interestingly, the effects of the Depression on the artists considered here were not entirely negative. Gorky, Pollock, de Kooning, Baziotes, Rothko, Gottlieb, Guston, and others were among the thousands of artists employed by government programs. The major programs were the Section of Fine Arts of the Treasury Department, and the Federal Art Project of the Works Progress Administration; the latter ad an easel division, for which artists submitted paintings done in any style in their own studios. The stipends enabled artists to "live modestly and nicely," as de Kooning recalled, and allowed him to put aside his other occupations, including carpentry and house painting, to focus on art. Beyond providing support, the projects created a sense of community among the artists involved: de Kooning met "all kinds of other painters and sculptors and writers and poets and architects, all in the same boat." The value the artists placed on this is evidenced by Barnett Newman's complaint that "I paid a severe price for not being on the project with the other guys; in their eyes I wasn't a painter; I didn't have the label." See Ashton, The New York School, pp. 44-51; Ratcliff, The Fate of a Gesture, p. 27; Sandler, The Triumph of American Painting, pp. 5-7; and Richard D. McKinzie, The New Deal for Artists (Princeton: Princeton University Press, 1973).
} 
legitimacy of a distinctively American art led to improving market conditions. ${ }^{30}$

During the late 1940s and early '50s, galleries sympathetic to the new American

art were opened in New York at an increasing rate. Peggy Guggenheim had

opened her pioneering gallery, Art of this Century, in 1942, and within the next

few years showed the work of Pollock, Hofmann, Motherwell, Rothko, Baziotes,

Still, and others. When she left New York after the war her place was taken

by Charles Egan, Betty Parsons, Samuel Kootz, and Sidney Janis, all of whom

opened galleries later in the '40s. ${ }^{31}$ Looking back on this period, Barnett Newman

\footnotetext{
${ }^{30}$ Clement Greenberg was the first critic to recognize the importance of the accomplishments of Pollock and his contemporaries, and Greenberg's observations over time provide an interesting chronology of the growing demand for these artists' work. In 1949 he remarked that 'it remains as difficult as ever for a young American painter or sculptor working in an advanced mode to win real attention in New York." He blamed this on American galleries which, with only a few exceptions, preferred to exhibit modern European art, and showed "inhospitality toward almost everything new or adventurous in the latest American art;" Arrogant Purpose, p. 321. In 1952 Greenberg complained that Jackson Pollock was not appreciated: "If Pollock were a Frenchman, ... people would already be calling him 'maitre' and speculating in his pictures. Here in this country the museum dirctors, the collectors, and the newspaper critics will go on for a long time - out of fear if not out of incompetence - refusing to believe that we have at last produced the best painter of a whole generation;" Affrmations and Refusals, pp. 105-06. An indication of change appears in a biographical sketch of Pollock written in 1957: Greenberg notes that "it is only since 1952 or 1953 that Pollocks have been in steady demand;" Modernism with a Vengeance, p. 46. He expressed broader optimism about the market in a 1958 tribute to the dealer Sidney Janis, who had exhibited the work of Albers, Pollock, deKooning, Gorky, Rothko, Kline, and Motherwell: "The real issue was whether ambitious artists could live in this country by what they did ambitiously. Sidney Janis helped as much as any one to see that it was decided affirmatively;" ibid., p. 53. And in a 1962 essay Greenberg again dated the growth in demand for contemporary American art from the early '50s. Noting that New York's art world had deferred to Paris in judging quality, he recalled that Pollock had had a show in Paris in 1952, "and it made such an impression that ... his art began to be taken more seriously in certain quarters of the Paris art world than anywhere else, including New York. And along with Pollock, the new American abstract art began to be taken more seriously in the same quarters. As it then seemed to me, it was over a year before news of this effectively reached New York. From that time the success in America itself of the new American painting dates, at least as far as collectors and museums and art journalism are concerned;" ibid., p. 135.

${ }^{31}$ Geldzahler, New York Painting and Sculpture, pp. 30-31; Dore Ashton, The New York
} 
later recalled that "we had no general public ... There were just a few galleries: Peggy Guggenheim up until $1947 \ldots$ and between ' 47 and '52, you might say Betty Parsons, Charlie Egan, and to some extent Sam Kootz were the only places where any of us had an opportunity of presenting ourselves, of showing the work. It was not, in that sense, a true marketplace." 32 Initially established to show the work of the older artists, commercial success led these galleries also to seek out new, younger painters. The success of these dealers in turn attracted Eleanor Ward, Martha Jackson, Leo Castelli, Andre Emmerich, and other new dealers during the 1950s, and these newer entrants increasingly focussed their efforts on the rising generation of young artists, including Robert Rauschenberg and Jasper Johns. ${ }^{33}$ Instead of facing the prospect of having to find academic or other jobs to support themselves, as had many of the older painters, the younger artists increasingly entered a profession in which the strength of the market allowed them the possibility of devoting themselves exclusively to painting. The key to doing this was to attract the attention of gallery owners, critics, and other painters.

The expanding market for contemporary art during the 1950s, and beyond into the '60s, thus raised the rewards to successful innovation, and young artists

School: A Cultural Reckoning (Berkeley: University of California Press, 1972), pp. 132,168.

${ }^{32}$ John P. O'Neill, ed., Barnett Newman: Selected Writings and Interviews (New York: Alfred A. Knopf, 1990), p. 305.

${ }^{33}$ Sandler, The New York School, pp. 36-38; Watson, From Manet to Manhattan, pp. 285-90. 
could easily perceive these rewards. ${ }^{34}$ In 1954, at the age of 51, Adolph Gottlieb recalled that he had been aware of "the difficulties of the modern artist" from the beginning of his career: "By the age of $18 \mathrm{I}$ clearly understood that the artist in our society cannot expect to make a living from art; must live in the midst of a hostile environment; cannot communicate through his art with more than a few people; and if his work is significant cannot achieve recognition until the end of his life (if he is lucky), and more likely posthumously." ${ }^{35}$ In contrast, once they had had their first solo shows, Jasper Johns, Frank Stella, and a number of their contemporaries who came of age in the 1950 s would no longer have to concern themselves with the problem of supporting themselves in jobs that might allow them to paint in their spare time. ${ }^{36}$ As William Rubin, Director of the Museum of Modern Art, later observed: "By 1958, when Stella came to New York, the

\footnotetext{
${ }^{34}$ On the growth of the market for contemporary art, and the effect of this on the position of artists, see Diana Crane, The Transformation of the Avant-Garde: The New York Art World, 1940-1985 (Chicago: University of Chicago Press, 1987), pp. 1-11.

${ }^{35}$ Mary Davis MacNaughton, "The Paintings of Adolph Gottlieb, 1923-1974," (unpublished Ph.D. dissertation, Columbia University, 1981) p. 189.

${ }^{36}$ The shift in the career patterns described here was clearly perceived by members of the first generation of artists considered here. In 1962 the dealer Sidney Janis presented a show titled "The New Realism," that included the new Pop artists. Mark Rothko, Robert Motherwell, Adoph Gottlieb, and William Baziotes resigned from the Janis Gallery in protest. Taken by surprise, Janis pointed out that he had begun by mixing earlier generations of artists: "Here we had been showing Pollock cheek-by-jowl with Leger, and de Kooning with Mondrian, and Kline with Klee, but when we took up the next generation our artists were furious. They didn't want to be associated with these people who became artists overnight." Calvin Tomkins commented that "The Abstract Expressionists' anger was not really so hard to understand. They had struggled for many years in total obscurity ... The recognition that they had so recently and so arduously won was now being usurped, or so they believed, by a new generation of brash youngsters who had become 'artists overnight,' who had not earned anything the hard way;" Tomkins, Off the Wall: Robert Rauschenberg and the Art World of Our Time (New York: Doubleday, 1980), pp. 184-85.
} 
art-buying public had become convinced that Americans could produce major painting, worthy of comparison with the best of earlier European modern art. And it was now clear that this work could be sold at prices that made an artist's profession economically feasible." 37

The career of Helen Frankenthaler provides a striking example of how quickly an innovation by a young artist in the new environment of the 1950s could diffuse and establish the artist's place in the critical canon. Frankenthaler arrived in New York as a college senior in 1949 and became a friend of the influential critic Clement Greenberg, who introduced her to many of the Abstract Expressionists. She was particularly struck by the recent work of Jackson Pollock - "as if I suddenly went to a foreign country but didn't know the language, but ... had a passionate interest, and was eager to live there ... and master the language" - and by his unorthodox practice of spreading a canvas on the floor and dripping oil paint onto it. ${ }^{38}$ She began to experiment with pouring oil washes on unprimed canvas, and in 1952 she painted a large canvas that she titled Mountains and Sea. The day the painting was completed, the artist Friedel Dzubas, who shared Frankenthaler's studio, phoned Greenberg to tell him "something odd and brilliant had emerged." 39 Greenberg saw the painting that evening, and agreed with Dzubas:

\footnotetext{
${ }^{37}$ William S. Rubin, Frank Stella (New York: Museum of Modern Art, 1970), p. 41.

${ }^{38}$ Sandler, The New York School, pp. 59-60

${ }^{39}$ Ratcliff, The Fate of a Gesture, p. 220.
} 
the picture was "finished' and shouldn't be touched." 40 Soon thereafter, Greenberg arranged for two painters from Washington, D.C., to see the painting in Frankenthaler's studio. One of them, Kenneth Noland, later described their reaction: "We were interested in Pollock but could gain no lead from him. He was too personal. But Frankenthaler showed us a way - a way to think about, and use color." 41 Even more succinctly, the other visitor, Morris Louis, declared that Frankenthaler was "a bridge between Pollock and what was possible." 42

In an essay written in 1960, Greenberg identified Louis and Noland as two of the best young American artists. Greenberg wrote that Louis "found himself only some seven or eight years ago ... His first sight of the middle-period Pollock and of a large and extraordinary painting done in 1952 by Helen Frankenthaler, called Mountains and Sea, led Louis to change his direction abruptly." Greenberg argued that the "crucial revelation" from Pollock and Frankenthaler "liberated Louis' originality along with his hitherto dormant gift for color." In Greenberg's opinion this achievement was substantial, as he concluded that "Louis, Noland, and Sam Francis are the only painters to have come up in American art since that 'first wave' [Pollock's generation] who approach its level." 43 In the introduction

\footnotetext{
${ }^{40}$ Sandler, The New York School, p. 62.

${ }^{41}$ Diane Waldman, Kenneth Noland: A Retrospective (New York: Solomon R. Guggenheim Museum, 1977), p. 17.

${ }^{42}$ Sandler, The New York School, p. 231.

${ }^{43}$ Greenberg, Modernism with a Vengeance, pp. 96-100.
} 
to a 1965 exhibition, Michael Fried provided a similar analysis of causation for Kenneth Noland, observing that "Noland's first wholly individual paintings date from 1958-59. They are executed in a stain technique deriving ultimately from Pollock's black stain paintings of 1951 by way of Helen Frankenthaler." Fried shared Greenberg's opinion of the importance of the development: "the formal issues with which Pollock and subsequent modernists such as Louis, Noland, Olitski, and ... Stella have chosen to engage are of a phenomenological subtlety, complexity, and richness without equal since Manet." ${ }^{44}$

Today Mountains and Sea hangs in the National Gallery of Art; critic Carter Ratcliff has called it "an icon of postwar American art". ${ }^{45}$ Thus a single painting done by a 24-year-old artist embodied an innovation that was recognized the same day it was completed, and established that artist's place in the progression of American art before even a decade had passed. Although Frankenthaler has been successful throughout a long career that continues today, her most valuable, and most highly critically acclaimed, work remains that done during her twenties.

While Frankenthaler's case is unusual because of the extraordinary importance of a single painting, her early rapid attainment of the status of an important figure in American art is not unusual among the younger generation of artists

\footnotetext{
${ }^{44}$ Fried, Three American Painters, pp. 13, 26.

${ }^{45}$ Ratcliff, The Fate of a Gesture, p. 220.
} 
considered in this study. Jasper Johns, probably the most successful of this group, first became known even more abruptly and dramatically. The story of how this occurred has become as much a staple in the popular literature of the art world as that of Frankenthaler's discovery. Instead of a critic, it was the dealer Leo Castelli who found Johns, this time by chance, as a result of a visit to Robert Rauschenberg's studio, a floor above that of Johns. Less than a year later, in 1958, Johns had his first one-man show at Castelli's gallery. Thomas Hess, the editor of Artnews, saw Johns' work at Castelli's before the show, and put one of the paintings, Target with Four Faces, on the front of his magazine. Johns' first oneman show was thus announced on the cover of the most respected American art journal. When the show opened Alfred Barr, then Director of Collections at the Museum of Modern Art, bought Target with Four Faces and two other paintings for the museum, and persuaded the architect Philip Johnson to buy Johns' fivefoot long painting of the American flag as a future gift to the museum. ${ }^{46}$ When the show closed, at age 27 Johns had become a new star in the eyes of the major collectors of contemporary art. And shortly thereafter Clement Greenberg had articulated his achievement and its lineage. Greenberg argued that Johns' work contained an irony. A surface of uneven densities of paint, devised by de Kooning to create visual depth, was used to represent inherently flat objects -

\footnotetext{
${ }^{46}$ Ratcliff, The Fate of a Gesture, pp. 131-32, 140.
} 
numbers, targets, flags - and was thus shown to be superfluous to the goal of using the flat surface of the canvas to represent a flat image. Johns had brought "de Kooning's influence to a head": through "this 'dialectic' the arrival of Abstract Expressionism at ... representation is declared and spelled out." 47

In his first solo exhibit, the young Johns had furthermore become a source of new ideas for even younger artists. One of these, Frank Stella, was struck by "the idea of repetition" in Johns' flags, and appropriated it for the geometric black paintings that produced his own initial success - at his first one-man show, at Castelli's gallery just two years later in 1960 , when Stella was $24 .^{48}$ Even before the Castelli show, four of the black paintings had been included in an exhibit at the Museum of Modern Art, and one was purchased by the museum at the insistence of Alfred Barr. ${ }^{49}$ And just five years after the Castelli show, Michael Fried gave Stella a central place in the critical canon. Describing the black paintings as done "partly in direct response to the work of Barnett Newman," Fried argued that they "amounted to the most extreme statement yet made advocating the importance of the literal character of the picture-support for the determination of pictorial structures," and consequently represented "the culmination of a tendency visible in the work of Manet if not earlier." 50 Although influential

\footnotetext{
${ }^{47}$ Greenberg, Modernism with a Vengence, pp. 126-27.

${ }^{48}$ Rubin, Frank Stella, p. 12.

${ }^{49}$ Ratcliff, The Fate of a Gesture, pp. 235-36.

${ }^{50}$ Fried, Three American Painters, pp. 40-41.
} 
critics continued to debate both the sources of Stella's early work and the proper interpretation of it - i.e. which problem he had chosen and how he had solved it none challenged its importance. ${ }^{51}$ Rather, as representatives of different factions within contemporary painting claimed him as their own, the debate assumed the importance of Stella, and particularly of his early work.

A systematic indication of how greatly the environment facing young artists changed during the 1950 s is given by Table 6 , which lists the ages at which the artists considered in this study had their first one-person gallery shows in New York. Although there are some significant exceptions of artists who had earlier gained success elsewhere, for most of these artists their first New York exhibit was an important event in their careers, analogous to the debut of an actor or musician. The table shows considerable variation among artists, but there is a clear decline over time in the typical age of an artist's debut: the median age at the time of the first New York show falls from 43 for artists born before 1910 to 32 and 33 for those born in the 1910 s and '20s, respectively, and further to 27 for those born in the 1930s. Whereas only 4 of 20 artists born through 1920 had their first New York shows while in their 20s, this became normal for the next generation, as 14 of 22 born after 1920 debuted while still in their 20 s. This dramatic decline in the age at which many artists gained their first opportunity

${ }^{51}$ Ratcliff, The Fate of a Gesture, pp. 233-35; Rubin, Frank Stella, pp. 53-60, 149. 


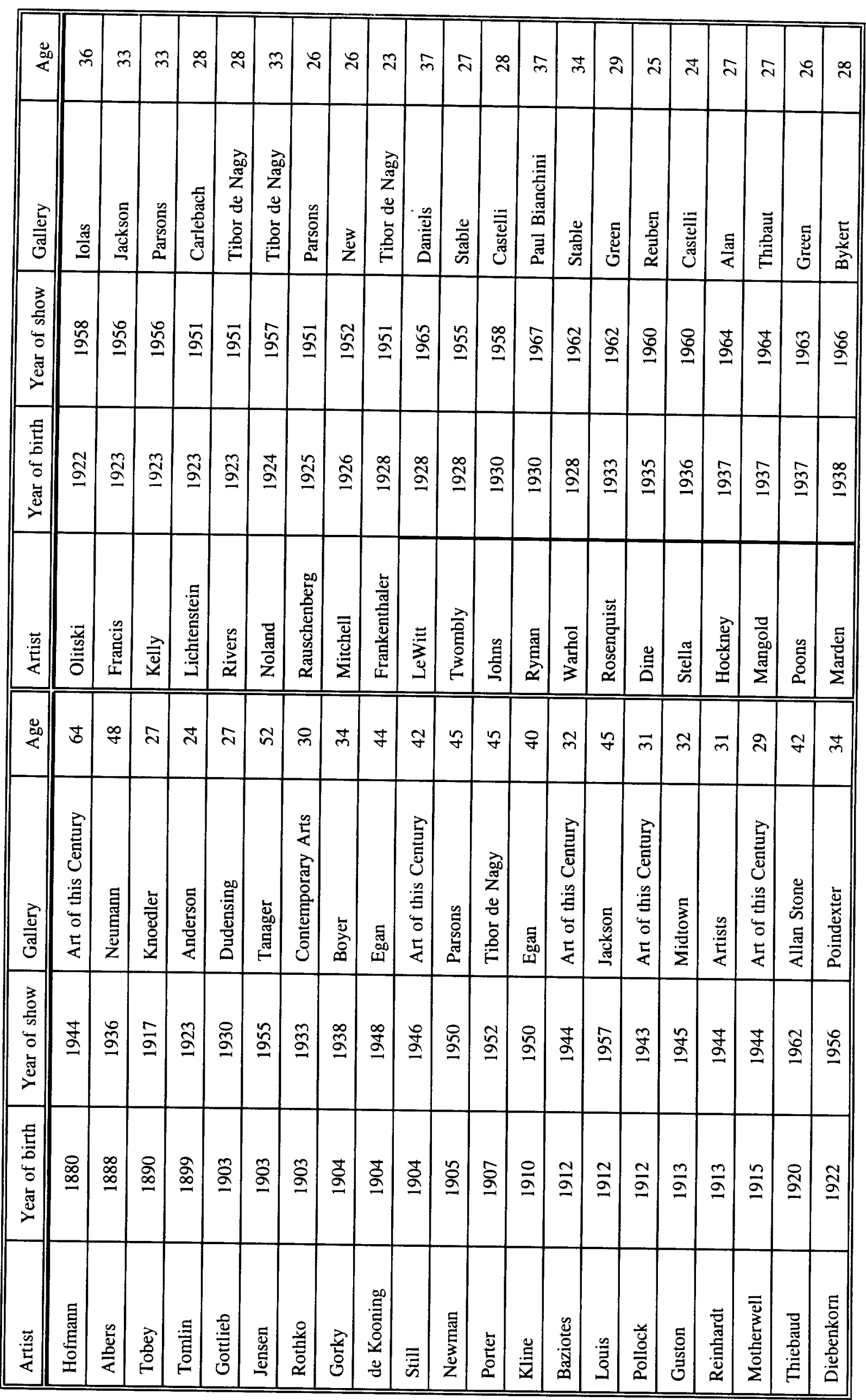


Table 6: (continued)

Sources: 429-50.

Henry Geldzahler, New York Painting and Sculpture: 1940-1970 (New York: E. P. Dutton, 1969), pp.

Irving Sandler, The Triumph of American Painting: A History of Abstract Expressionism (New York:

Praeger, 1970), pp. 277-80.

Irving Sandler, The New York School: The Painters and Sculptors of the Fifties (New York: Museum of Modern Art, 1962), p. 90.

Karen Tsujimoto, Wayne Thiebaud, (Seattle: University of Washington Press, 1985), p. 171.

Wendy Weitman, Sol LeWitt: Prints 1970-1995 (New York: Museum of Modern Art, 1996).

Alfred Jensen, Alfred Jensen: Paintings and Diagrams from the Years 1957-1977 (Buffalo: Albright-

Knox Gallery, 1978), p. 92.

Heiner Bastian, ed., Cy Twombly: Catalogue Raisonne of the Paintings, Vol. 1 (Berlin: Schirmer, Mosel, 1992), p. 280.

Klaus Kertess, Brice Marden (New York: Abrams, 1992).

Peter Clothier, David Hockney (New York: Abbeville, 1995), p. 119.

Edy de Wilde, Robert Mangold (Amsterdam: Stedelijk Museum, 1982).

Robert Storr, Robert Ryman (London: Tate Gallery, 1993), p. 216. 
to become economically successful provides concrete evidence of the impact of the growing demand for contemporary art on artists' careers.

\section{Conclusion}

Econometric analysis of auction sales of paintings reveals that successful American artists born in the 1920 s and ' 30 s are much more likely to have done their most valuable work at an early age than were their counterparts born between 1900 and 1920. Comparing these results to art textbooks and the composition of retrospective exhibitions furthermore demonstrates that these artists' most valuable work has also been that most highly regarded by art historians and critics.

The implied shift in career patterns across generations appears to have been a result of changes in both the nature of modern painting and in the market for contemporary art. With a growing emphasis on the importance of solving formal problems in painting, youth may not only have become less of a barrier to doing significant work, but may actually have become an advantage: painting may have become one of the many disciplines in which "startling and spectacular" improvements in the existing technology are routinely made by the young. ${ }^{52}$ The growth of the demand for contemporary American art in the 1950s and '60s heightened the demand for such innovations: the growth of the market made

\footnotetext{
${ }^{52}$ For a survey of these disciplines, see Dean Keith Simonton, Scientific Genius: A Psychology of Science (Cambridge: Cambridge University Press, 1988), pp. 66-74.
} 
young artists more aware of the rewards for innovation at the same time that it increased the probability that innovative work would be seen and recognized.

The growing tendency for the most valuable and important work of successful artists born after 1920 to be done early in their careers was therefore a product of changes in both the practice of art and the market for it: the evolution of modern painting made success early in a career possible, while the expansion of the market for contemporary art allowed a new generation of American artists to take advantage of this and become established much more quickly than those who had preceded them. 


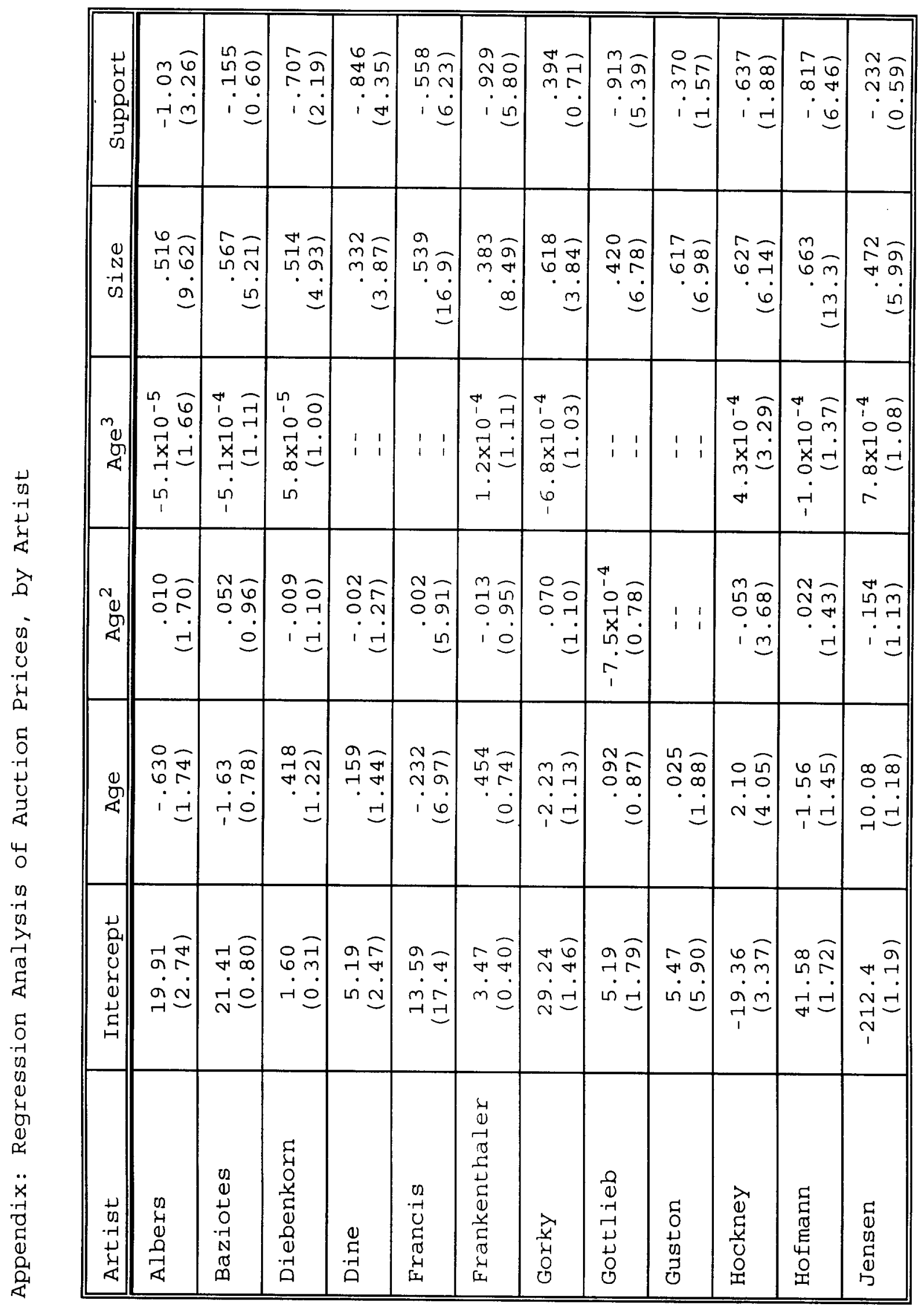




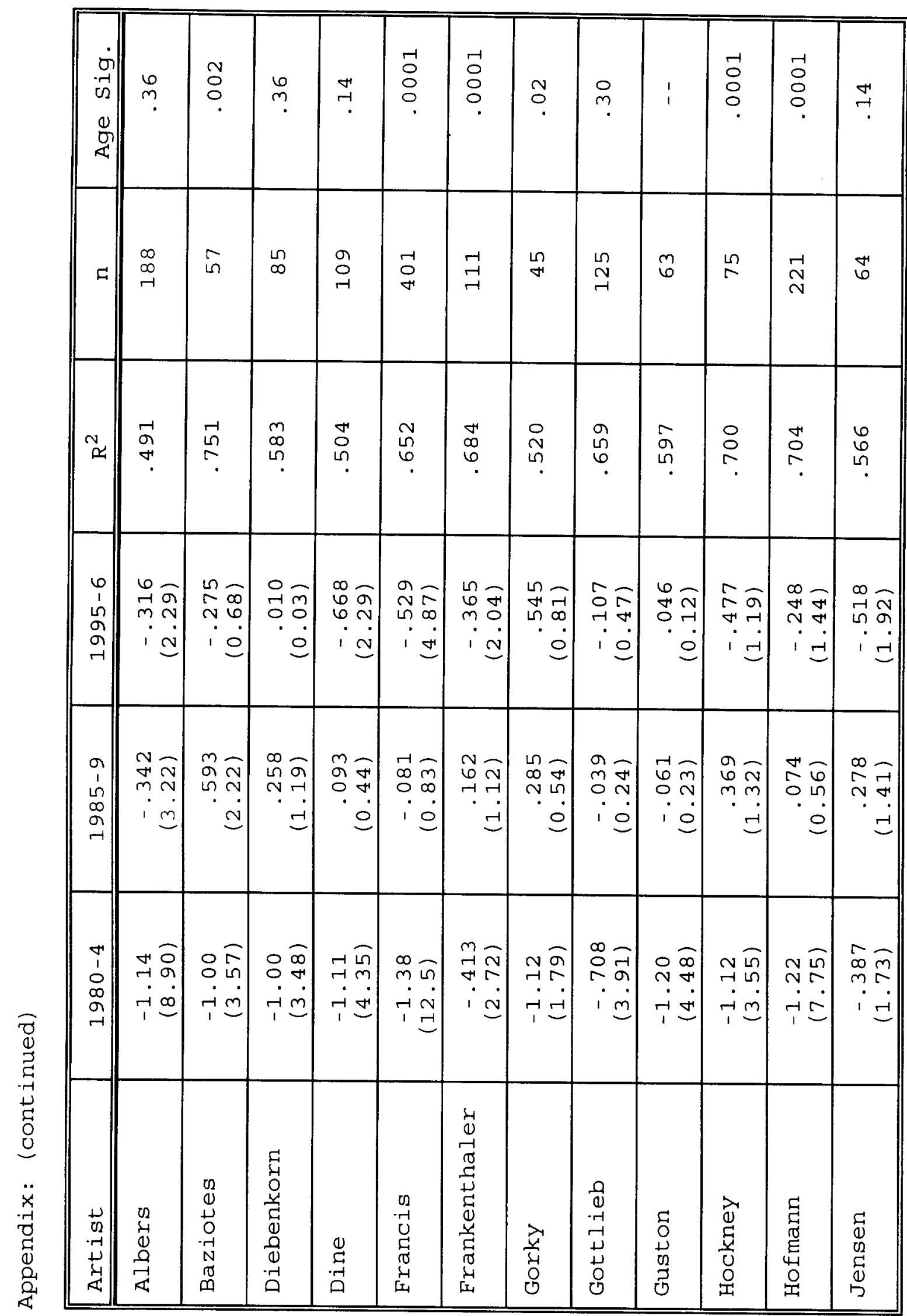




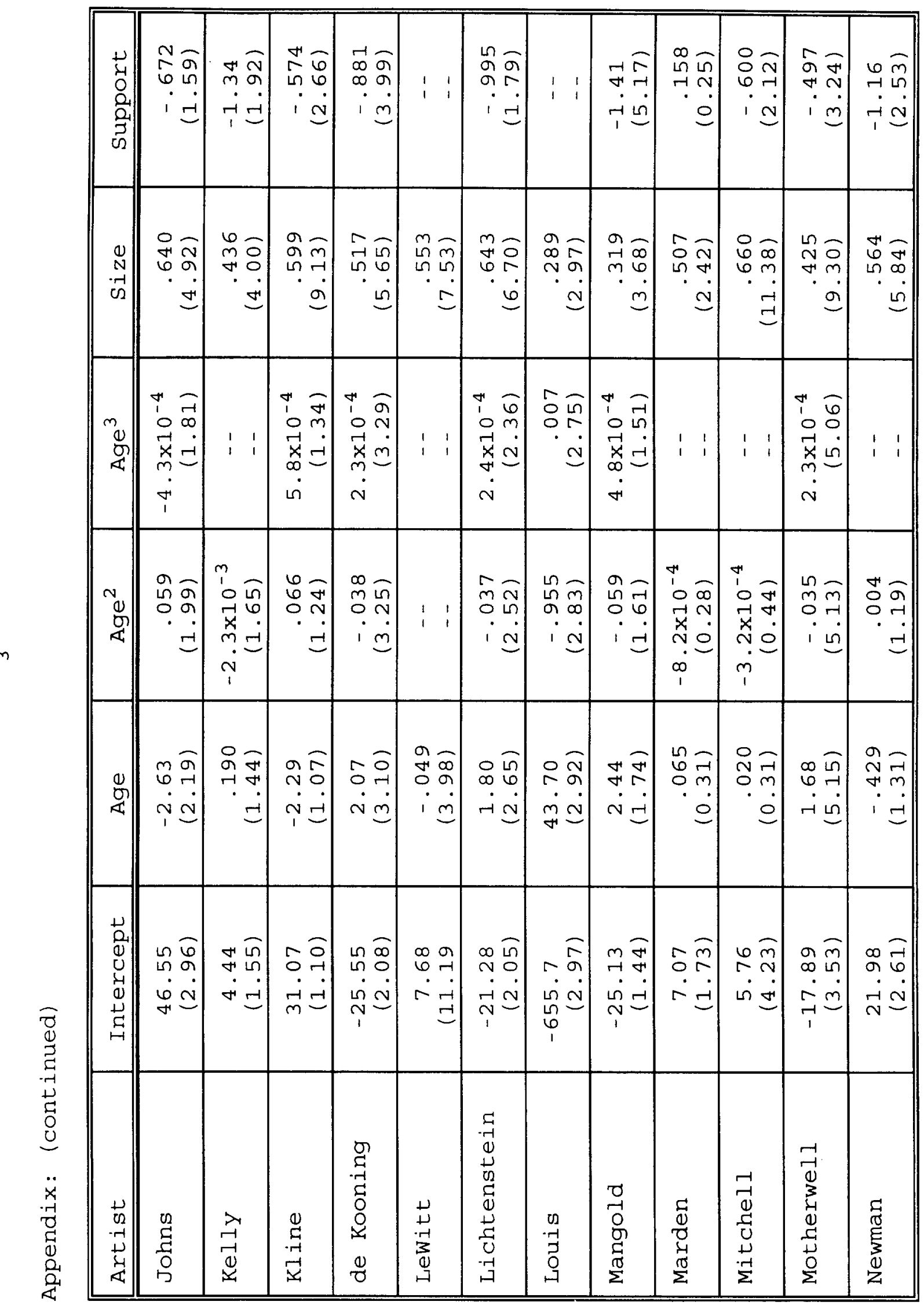




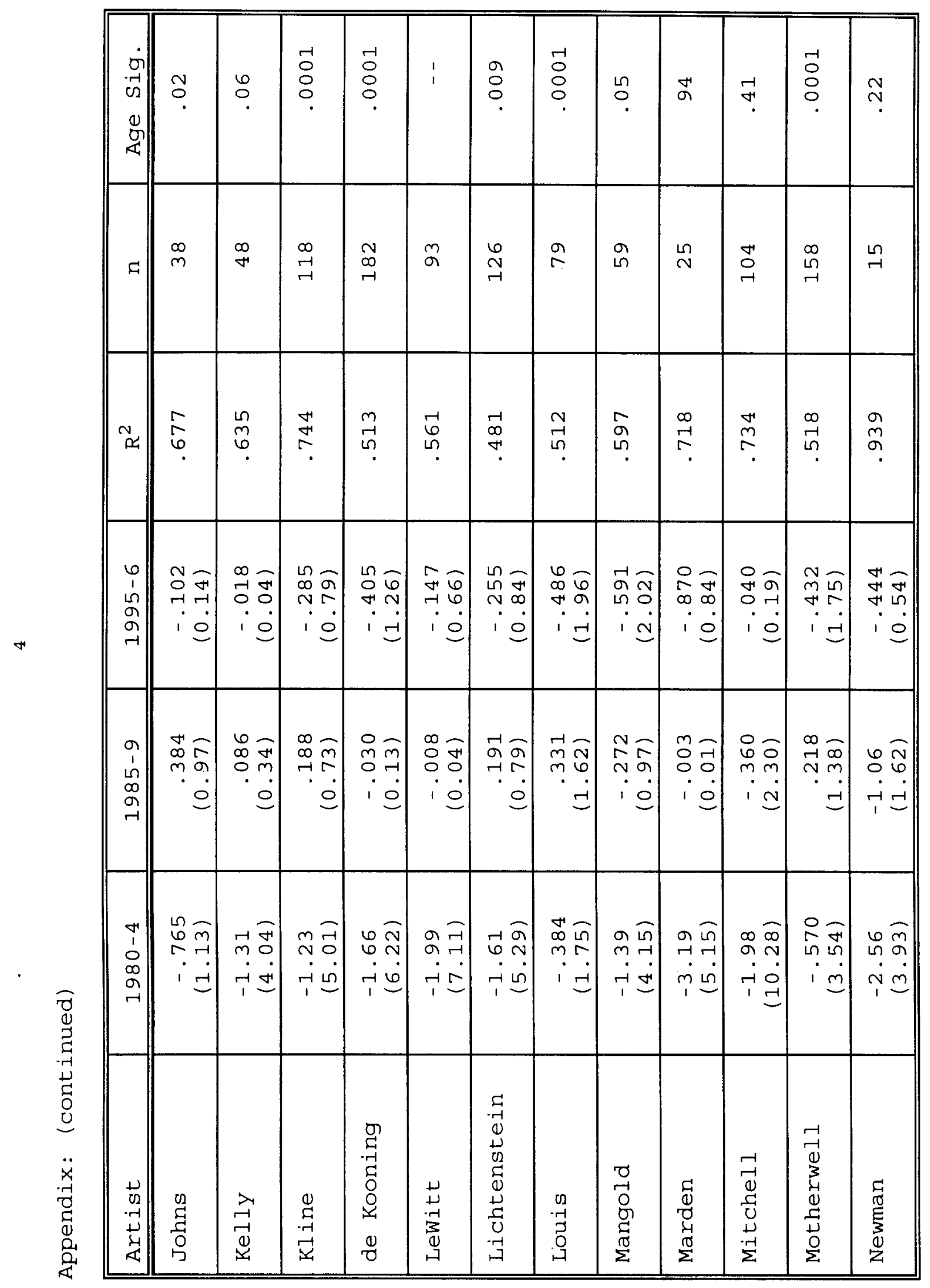




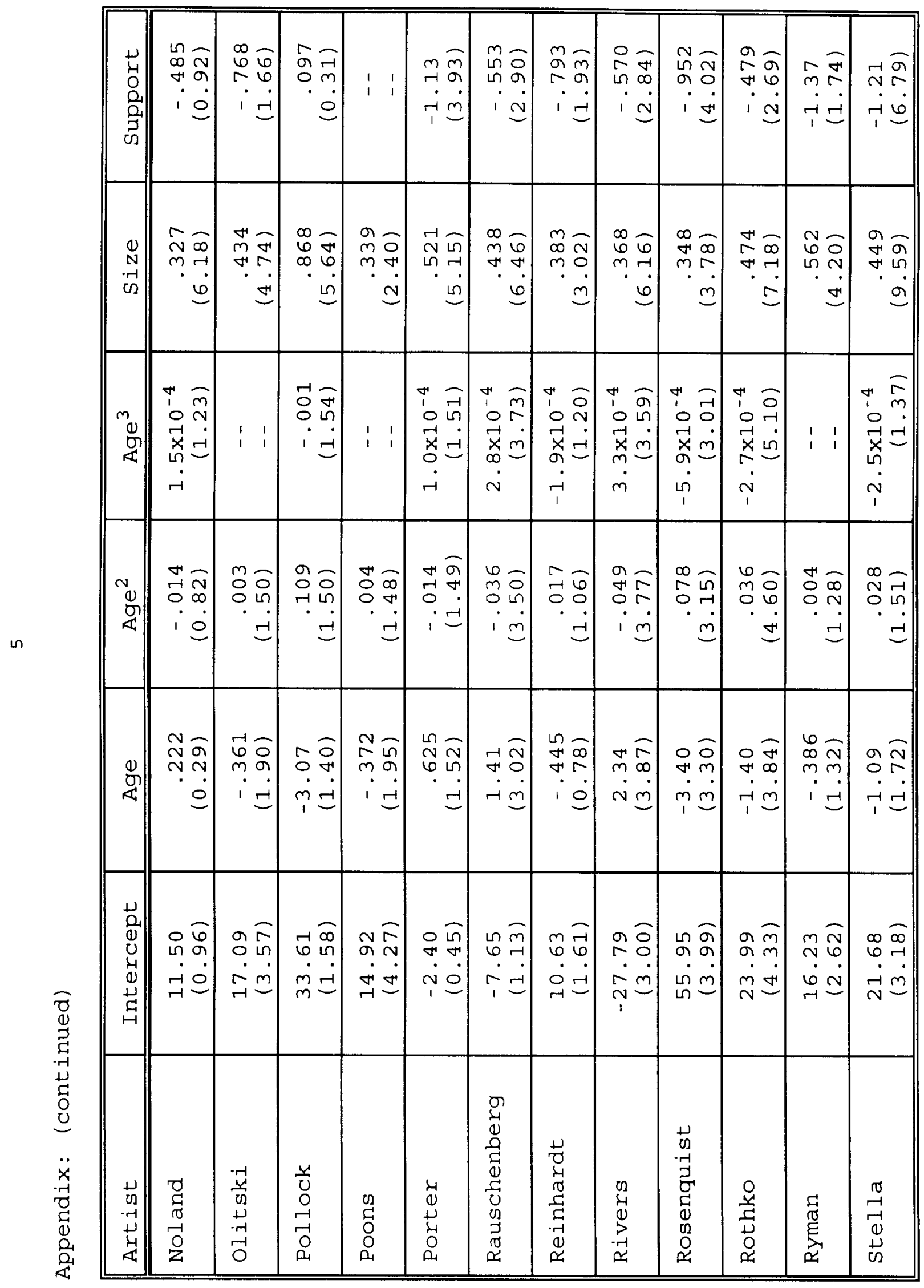




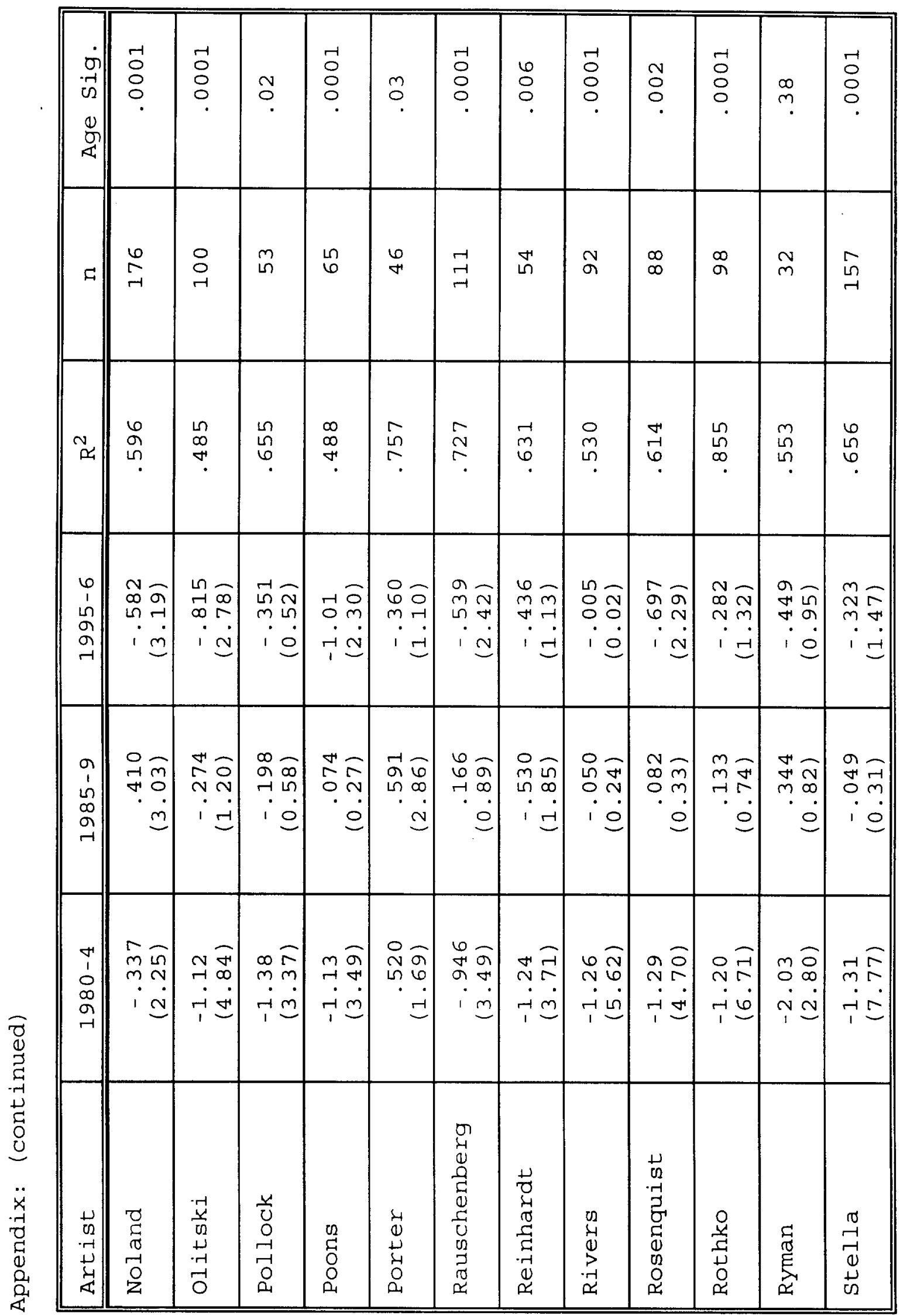




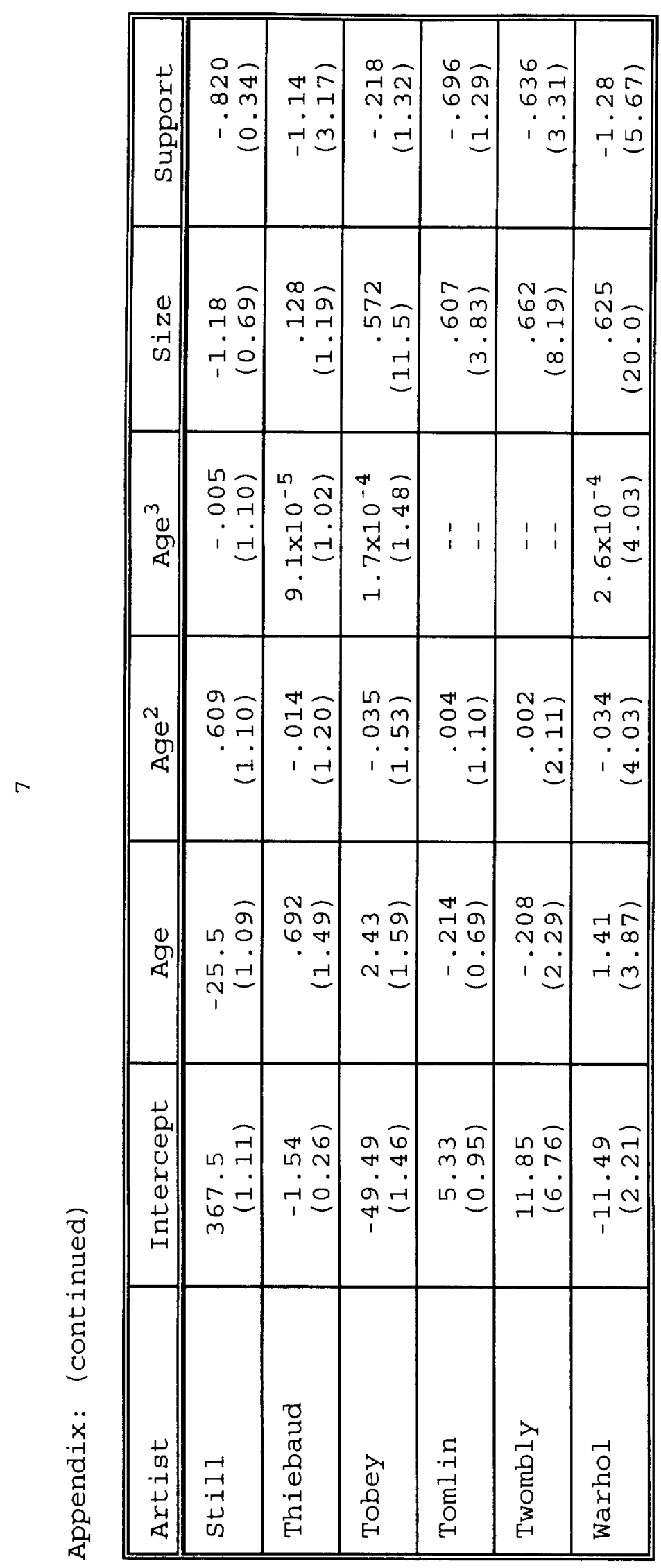




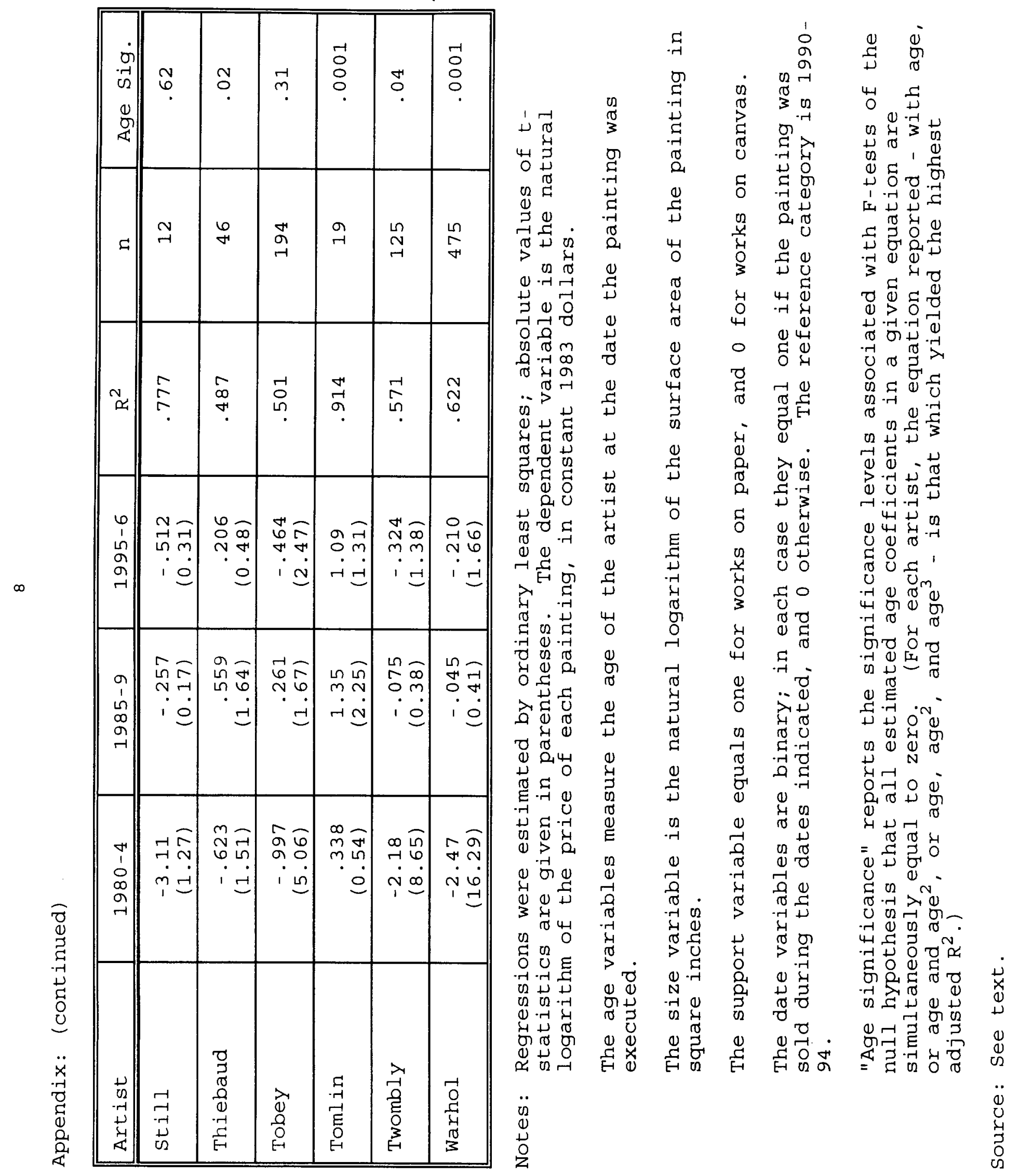



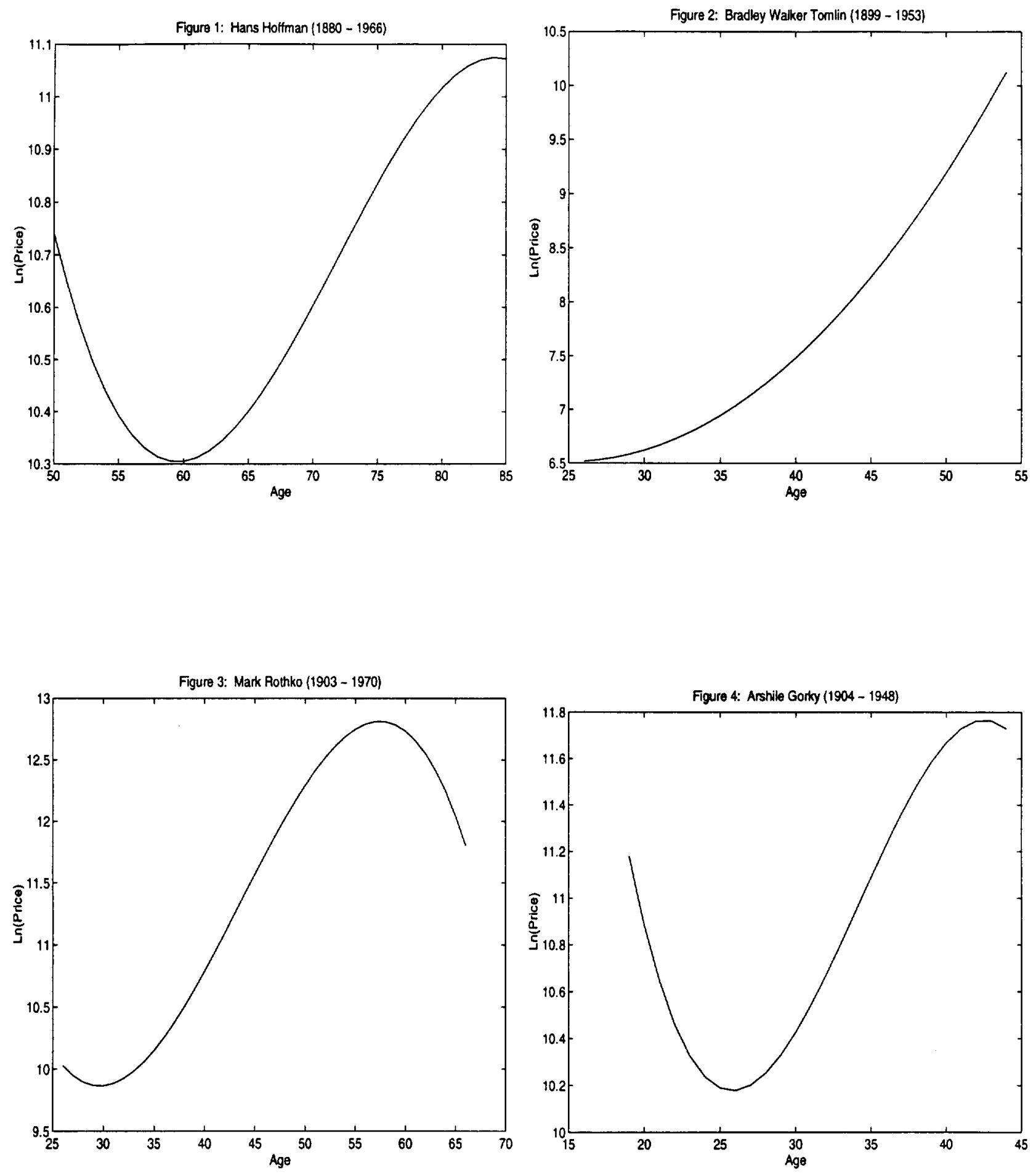

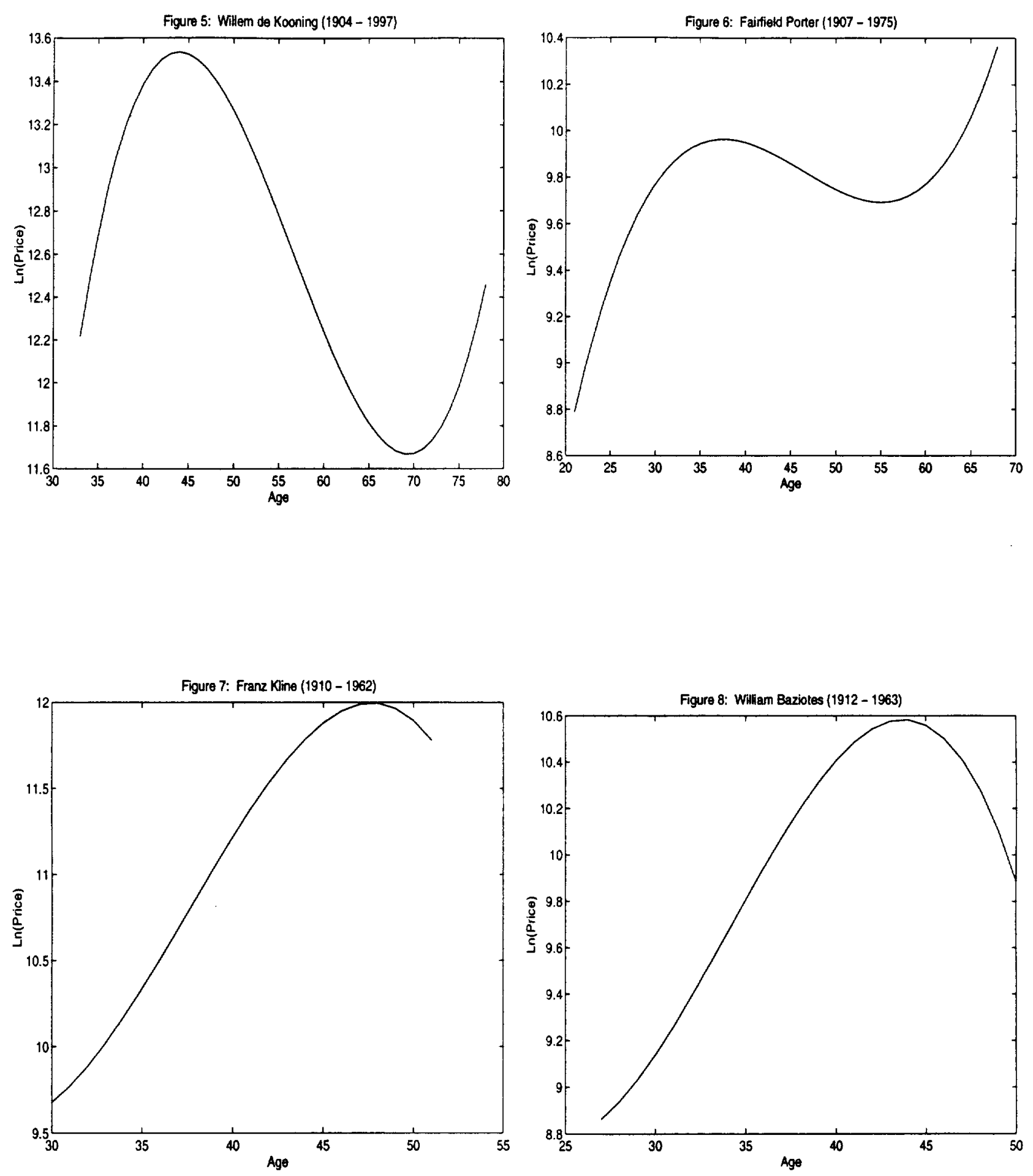

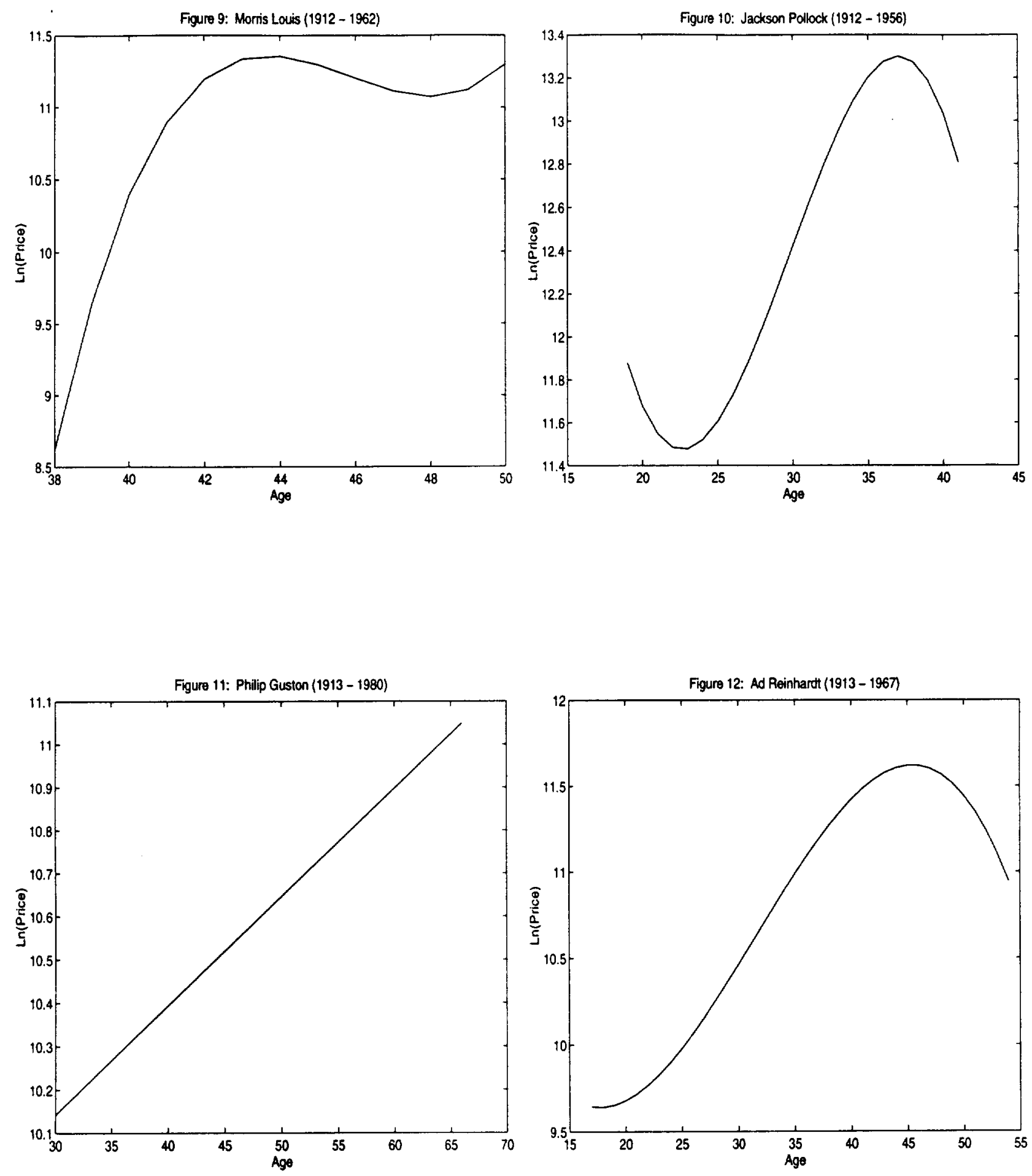

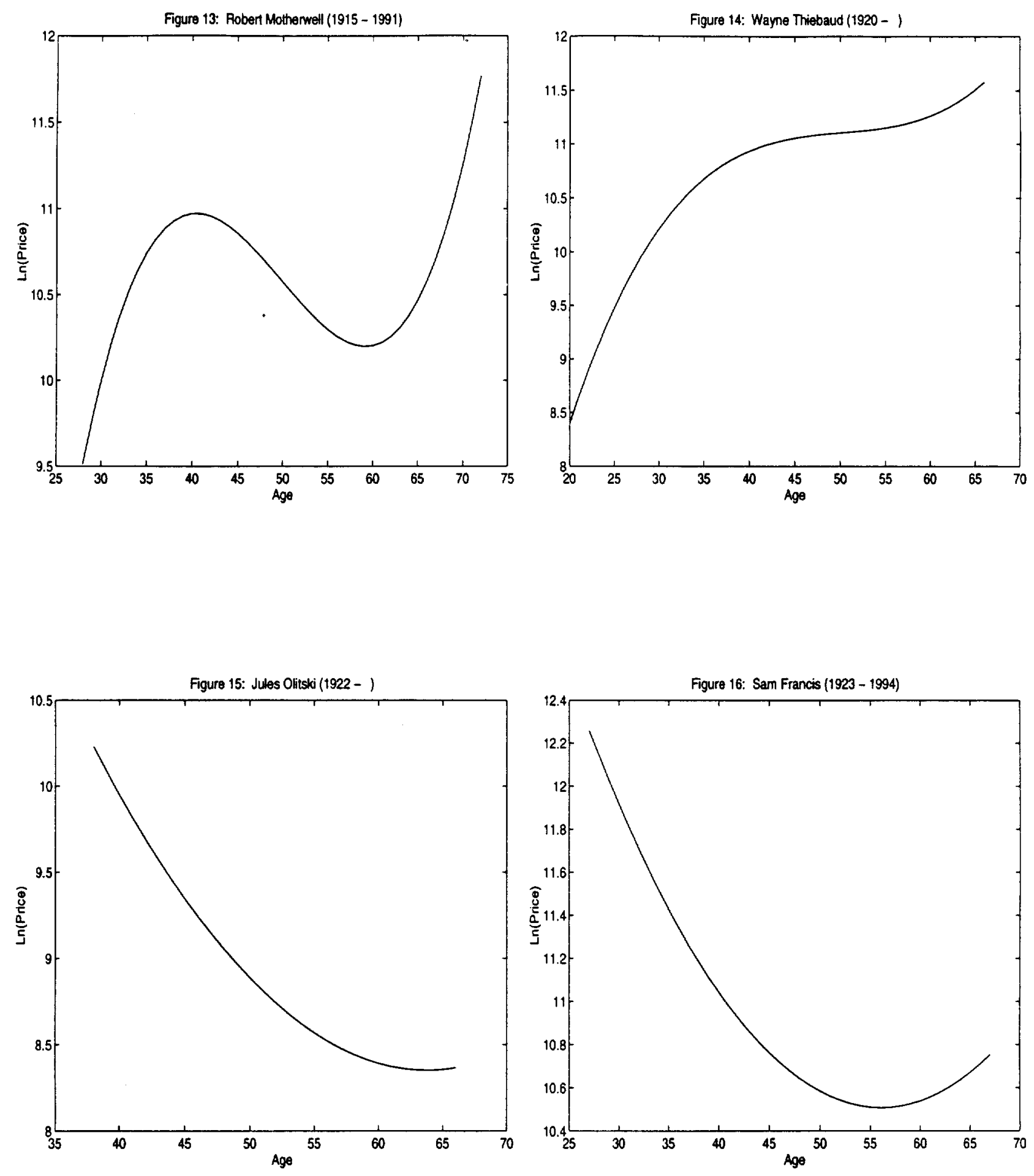

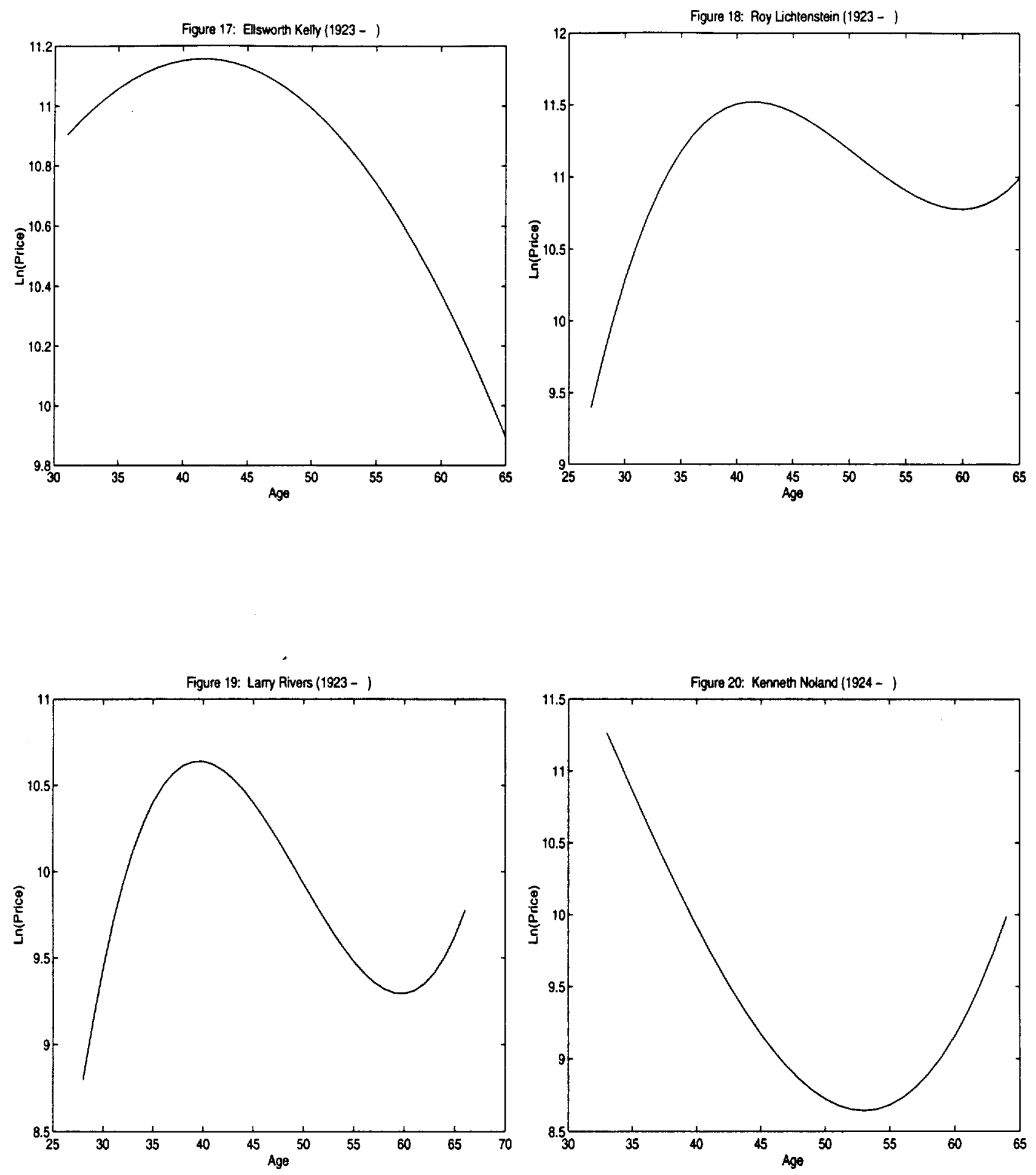

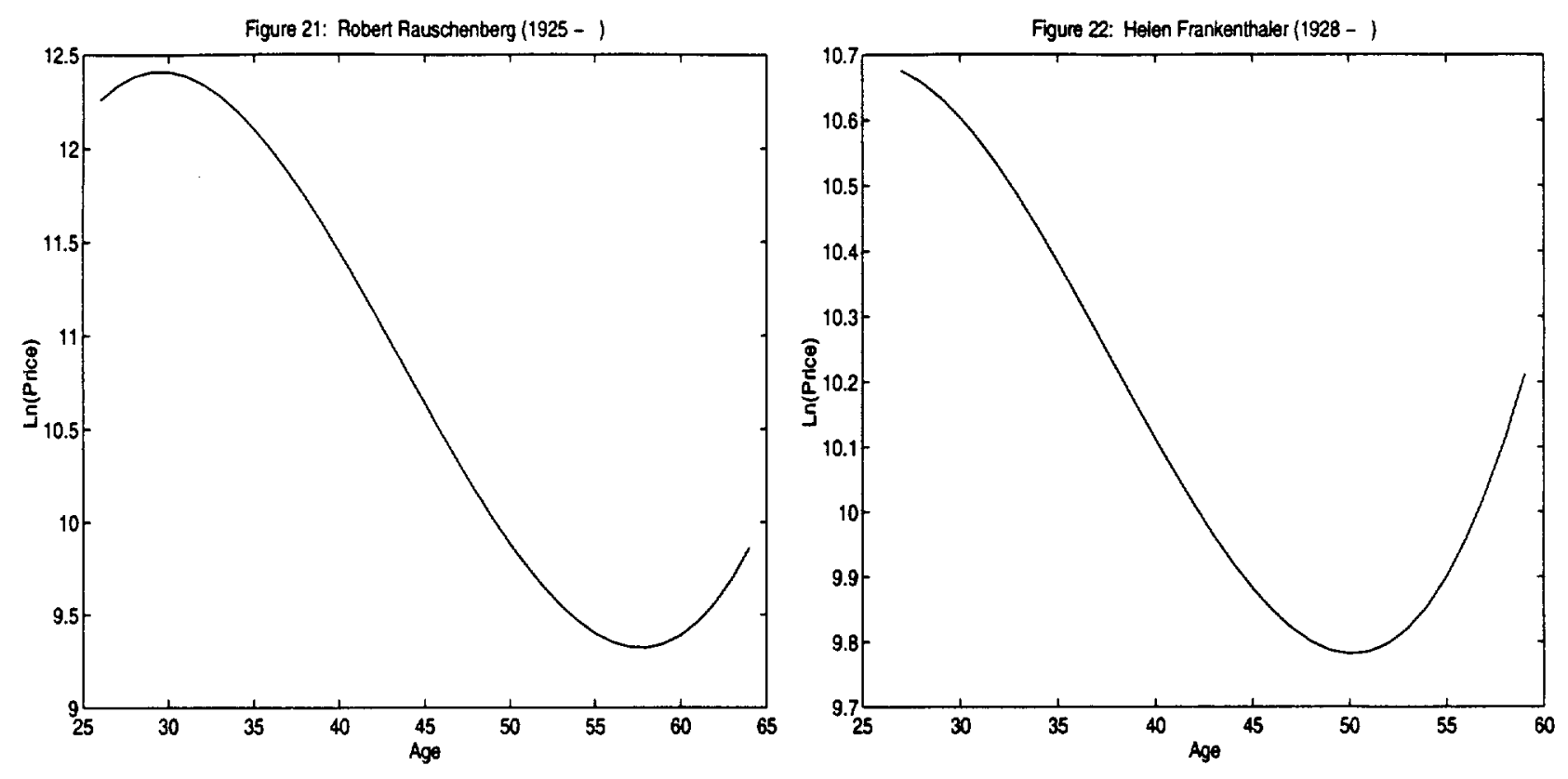

Figure 23: Sol LeWitt (1928 - )
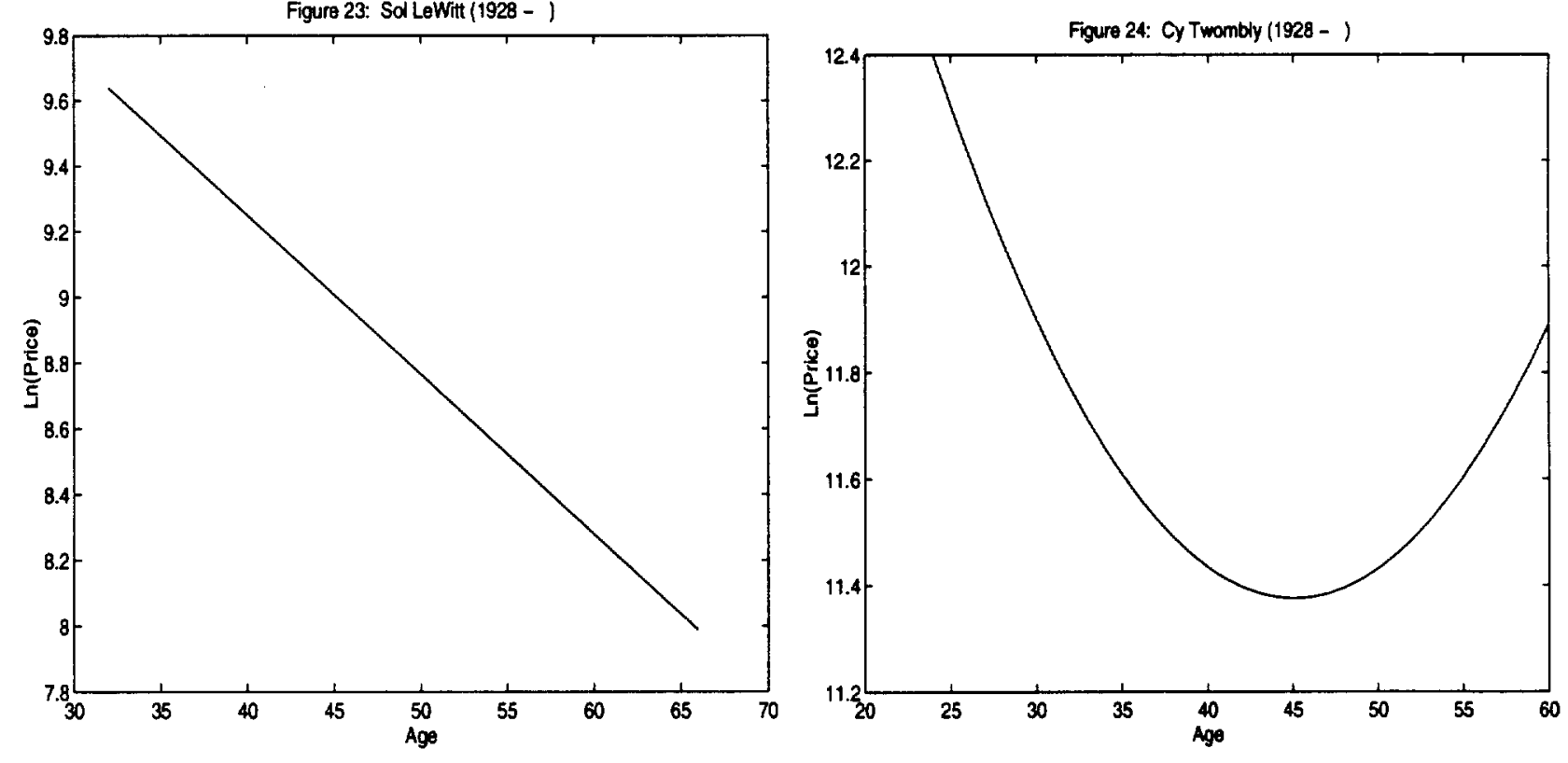

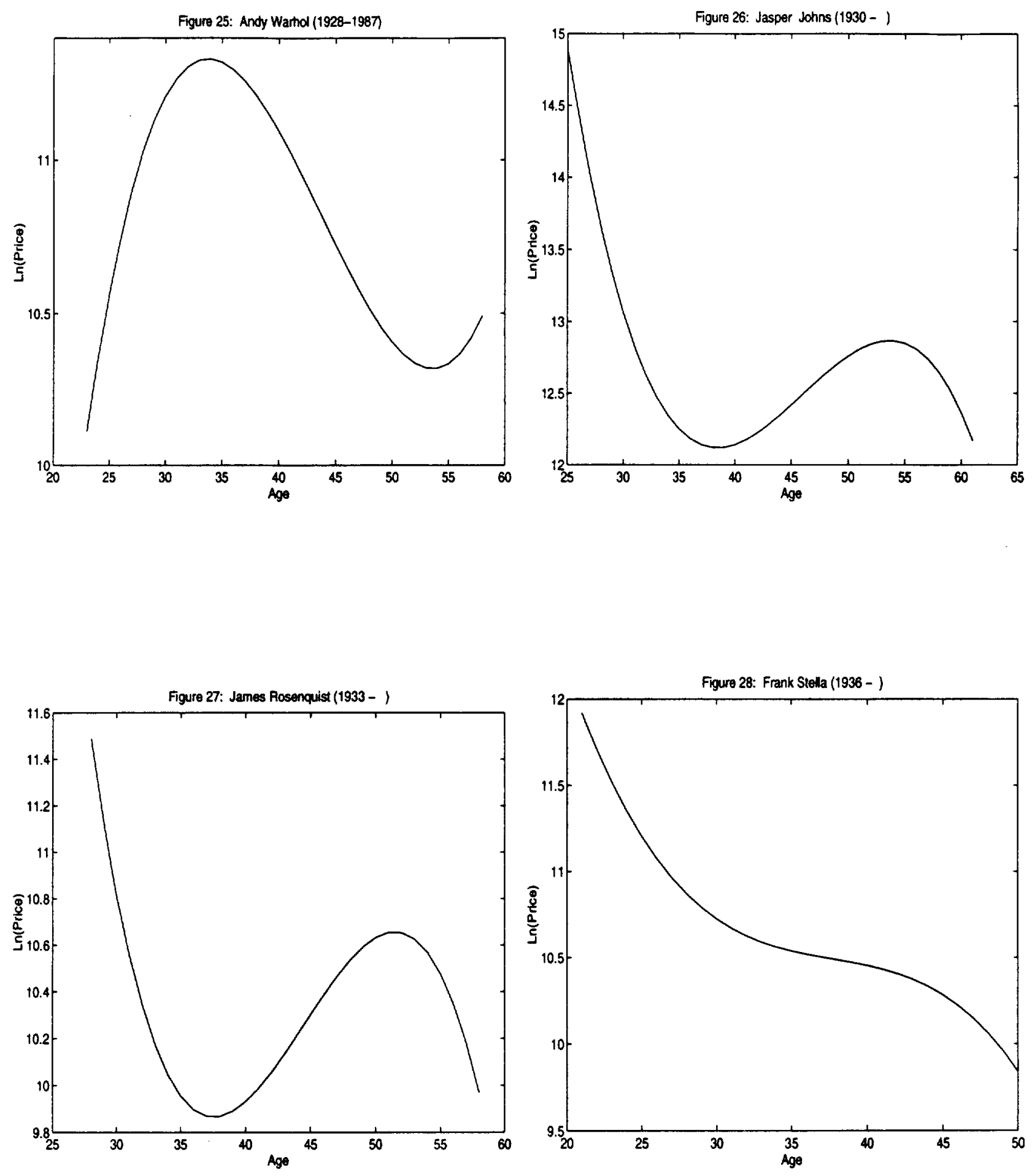

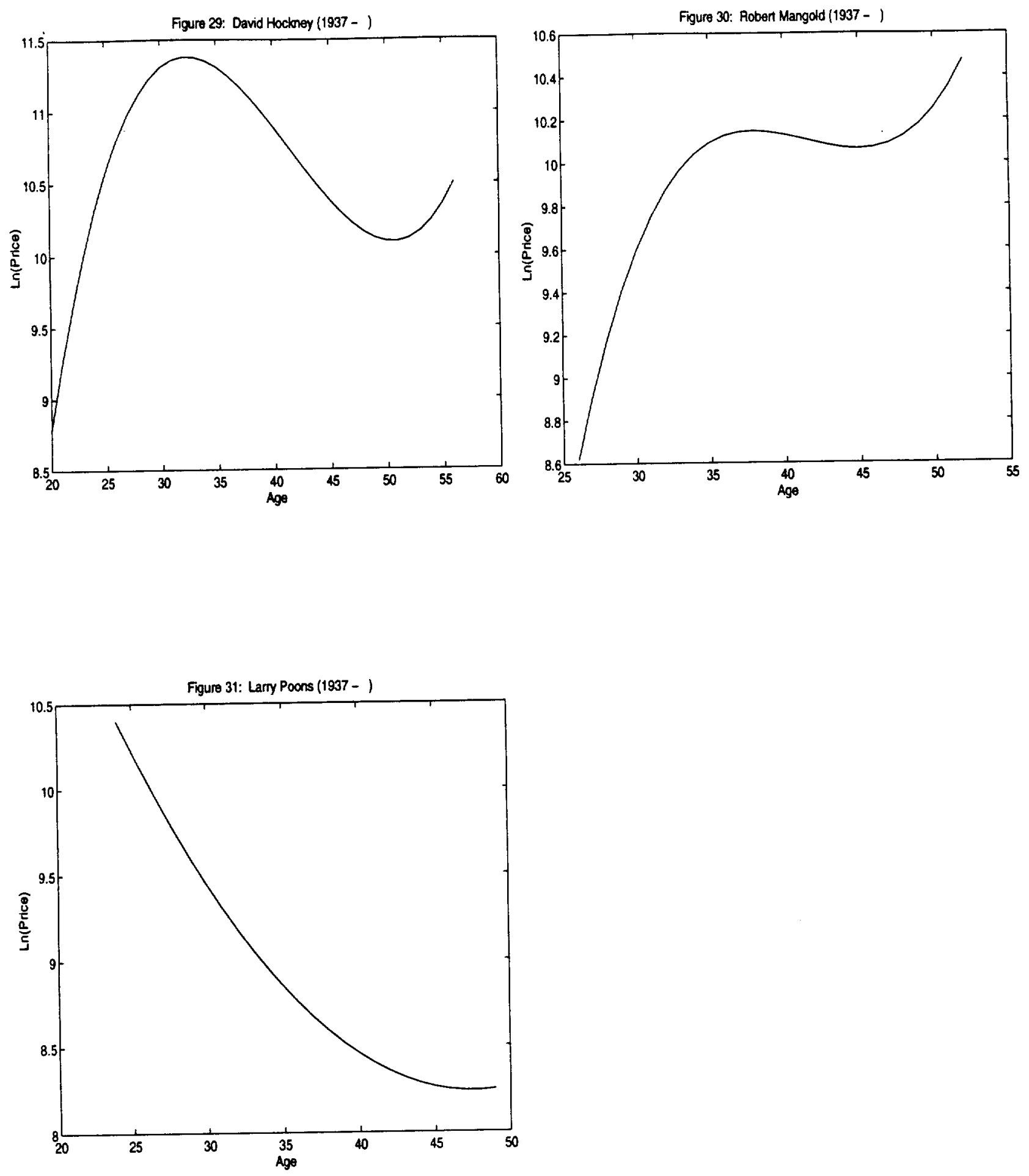